\title{
ANTHROPOGENIC IMPACTS ON THE WESTERN SECTOR OF SEPETIBA BAY (SE BRAZIL) ASSESSED BY THE PB ISOTOPIC COMPOSITION OF SURFACE SEDIMENTS
}

\section{Shéron Joyce díaz Morales ${ }^{1}$, Josefa Varela Guerra ${ }^{1}$, Márcia Andréia da Silva Nunes ${ }^{2}$, Maria Virgínia Alves MARTins ${ }^{3,4}$, ARIADNE MARra DE SOUZA ${ }^{5}$ AND MAURo CÉSAR GERALDES ${ }^{3 *}$}

1 Universidade do Estado do Rio de Janeiro, Faculdade de Oceanografia, Rua São Francisco Xavier, 524, $4^{\circ}$ andar, bloco E, sala 4028, Maracanã, Rio de Janeiro, RJ, Brazil

2 Universidade do Estado do Rio de Janeiro, Faculdade de Geologia, Programa de Pós Graduação em Geociências, Rua São Francisco Xavier, 524, sala 4024, bloco A, Maracanã, Rio de Janeiro, RJ, Brazil

3 Universidade do Estado do Rio de Janeiro, Faculdade de Geologia, Rua São Francisco Xavier, 524, Maracanã, Rio de Janeiro, RJ, Brazil

4 Universidade de Aveiro, GeoBio'Tec, Departamento de Geociências, Campus de Santiago, 3810-193 Aveiro, Portugal.

5 Universidade Federal do Espírito Santo (UFES), Centro de Ciências Exatas, Naturais e da Saúde, Alto Universitário s/n, Alegre - ES, Brazil

* CoRRESPONDING AUTHOR, geraldes@uerj.br

Received on 03 July 2019

Received in revised form on 04 September 2019

Accepted on 07 September 2019

Editor: Maria Antonieta da Conceição Rodrigues, Universidade do Estado do Rio de Janeiro

\section{Abstract}

In this work are presented lead $(\mathrm{Pb})$ concentrations and $\mathrm{Pb}$ isotopes ratios $\left({ }^{204} \mathrm{~Pb},{ }^{206} \mathrm{~Pb},{ }^{207} \mathrm{~Pb},{ }^{208} \mathrm{~Pb}\right)$, determined by leaching and total dissolution techniques, from surface bottom sediment samples collected in the western sector (outer region) of Sepetiba Bay, Rio de Janeiro (SE Brazil). The main aim of this work was to identify possible sources of $\mathrm{Pb}$, particularly those related to anthropogenic activities in the study area. The $\mathrm{Pb}$ isotopic signature of the analyzed sediments was compared to data obtained in other studies performed in Sepetiba Bay and other Brazilian regions, including records of pre- and post-industrial activity. In the outer region of Sepetiba Bay, the ${ }^{206} \mathrm{~Pb}^{/ 207} \mathrm{~Pb}$ ratios ranged from 1.160 to 1.259 for the total dissolution technique and from 1.175 to 1.188 for the leaching technique. This isotopic

\section{Introduction}

Sepetiba Bay is a $520 \mathrm{~km}^{2}$ semi-enclosed coastal water body, located approximately $60 \mathrm{~km}$ west from the metropolitan region of Rio de Janeiro, SE Brazil (Pellegatti, 2000). It is connected with the South Atlantic waters through two entrances, one in the western sector, between the strings of islands bounded by the edge of Marambaia Barrier Island, and the other in the eastern sector, through a small and shallow water channel that debouches in Barra de Guaratiba (Fig. 1; Montezuma, 2007). Sepetiba Bay is an industrial and port center of great prominence and so a strongly
Citation:

Díaz Morales, S.J., Guerra, J.V., Nunes, M.A.S, Alves Martins, M.V., Souza, A.M., Geraldes, M.C., 2019. Anthropogenic impacts on the western sector of Sepetiba Bay (SE do Brazil) accessed by the $\mathrm{Pb}$ isotope composition of surface sediments. Journal of Sedimentary Environments, 4 (3): 291-311.

signature is similar to that obtained in previous studies carried out in the eastern and northeastern inner areas of this bay, which is under strong urbanization and industrial pressures. The $\mathrm{Pb}$ isotopic signature obtained by the integrated use of total dissolution and leaching techniques allowed to trace the presence of sediments from highly contaminated areas located in the eastern and northeastern sectors of Sepetiba Bay, probably as a consequence of dredging activities and natural sediment dispersion processes.

Keywords: $\mathrm{Pb}$ Isotopes. Geochemistry. Anthropogenic activities. Sediment source. Dredging impact. Coastal area.

anthropized region (Moraes, 1999; FEEMA, 2006; Neto et al., 2006; FIRJAN, 2012; Ecologus, 2014, 2016; Moreno and Kato, 2015; Ribeiro et al., 2015).

According to statistics from 1998, the industrial complex installed in Sepetiba Bay was composed by a total of 100 industries. Currently about 400 industrial enterprises are installed in this region (Neto et al., 2006; Costa et al., 2011). Potentially toxic industries, whose main environmental contamination is by trace metals, are located in the cities from the Rio de Janeiro metropolitan region, such as Nova Iguaçu, Queimados, Itaguaí and Santa Cruz, located within a 
radius of 18 to 27 kilometers from Sepetiba Bay (Fig. 1; Rio de Janeiro, 2001). Another factor that contributes to the environmental degradation of this bay is the use of the drainage basin of several rivers for the discharge of domestic and industrial effluents of several cities from Rio de Janeiro State (Fig. 1; Rio de Janeiro, 2001).

Sepetiba Bay receives contamination from several sources (Wasserman et al., 2001; Molisani et al., 2004; Pellegatti et al., 2007; Ferreira, 2009; Rocha et al., 2010; Patchineelam et al., 2011; Ferreira and Moreira, 2015; Díaz Morales et al., 2019), which cause problems for living organisms and the ecosystem (Ferreira and Horta, 2010; Miranda Filho et al., 2011; Ferreira, 2011). Thus, it is difficult to identify and discriminate specific sources of contamination.

The analysis of trace metal concentrations is an efficient tool for the diagnosis of the environmental quality, but does not allow the identification of sources of pollution in different zones of this bay (Díaz Morales et al., 2019). However, it is possible to obtain isotope signatures of a site, through the determination of $\mathrm{Pb}$ stable isotopes ratios, which can be compared to the signatures of possible sources of pollution (Bollhöfer and Rosman, 2000; Pellegatti, 2000).

Lead has four fundamental isotopes that are used to monitor the environmental quality of several systems: ${ }^{204} \mathrm{~Pb}$, whose absolute abundance on Earth is stable, and ${ }^{206} \mathrm{~Pb}$, ${ }^{207} \mathrm{~Pb},{ }^{208} \mathrm{~Pb}$ which are daughter isotopes resulting from the radioactive decay of ${ }^{238} \mathrm{U},{ }^{235} \mathrm{U},{ }^{232} \mathrm{Th}$, respectively (Patterson et al., 1976). The analysis of pollution in sediments and soils through the use of $\mathrm{Pb}$ isotopes is based on the existence of a significant isotopic difference between natural $\mathrm{Pb}$ and $\mathrm{Pb}$ of industrial origin (Simonetti et al., 2000; Tarzia et al., 2002; Rusiecka et al., 2018). Published studies describe Pb from industrial origin, as less radiogenic, with a ${ }^{206} \mathrm{~Pb} / 204 \mathrm{~Pb}$ ratio between 16.0 and 19.5 (Hansmann and Köppel, 2000). In contrast, $\mathrm{Pb}$ originated from non-polluted soils, derived from weathered rocks, whose isotopic composition reflects the signature of the ratios of the source material, has been characterized as more radiogenic (Hansmann and Köppel, 2000). Some studies have been performed in the southern hemisphere, using atmospheric $\mathrm{Pb}$ isotopes as tracers of pollution sources in this hemisphere (Bollhöfer and Rosman, 2000). In Brazil, $\mathrm{Pb}$ isotopes were analyzed in the atmosphere of São Paulo city (Aily, 2000), in sediments from Paranoá Lake (Gioia et al., 2006) and sediments from the Guamá and Guajará river estuaries (Santos et al., 2012). In Rio de Janeiro State only a few studies, as those carried out in Guanabara Bay (Geraldes et al., 2006) and in the northern and central-eastern sectors of Sepetiba Bay (Cunha et al., 2009; Rocha, 2011) were executed.

This work is a contribution to the identification of possible sources of pollution to the western sector of Sepetiba Bay, (Fig. 1) by using results of $\mathrm{Pb}$ isotope signatures obtained from bottom surface sediments.

\section{Methods and Materials}

Surface sediment samples were collected on 10, 22 and 23 November 2010, west from Itacuruçá and Jaguanum islands. The sampled region borders Ilha Grande Bay and has a wide connection with the adjacent continental shelf. Sixty-five samples were collected with a Van Veen grab, onboard a small boat (stations S01 to S66; S = Sepetiba Bay) (Fig. 1). The sampling location coordinates are presented in Table 1.

Samples were taken from the center of the Van Veen grab, avoiding to collect sediment that was in contact with the equipment. The samples were stored in plastic bags, identified, and packed in Styrofoam with ice until they arrived at the laboratory, where they were stored in a freezer at $-10{ }^{\circ} \mathrm{C}$.

In this study, the preparation of the samples to obtain the extract for $\mathrm{Pb}$ isotope analysis followed the same techniques used in previous studies carried out in the northern and central-eastern sectors of Sepetiba Bay (Cunha et al., 2009; Rocha, 2011). The drying process was conducted in the Geological Samples Preparation Laboratory from the Geology Faculty of the Universidade do Estado do Rio de Janeiro (UERJ) through a light box at a temperature of about $80^{\circ}$ Celsius. Then, the sediments were homogenized using a mortar and pistil and then sifted through a set of sieves with $1.0 \mathrm{~mm}, 0.5 \mathrm{~mm}$ and $0.072 \mathrm{~mm}$ mesh diameters. Sediment fractions $<0.072 \mathrm{~mm}$ were stored in polyethylene bottles for lead analyses.

The quantification of $\mathrm{Pb}$ isotopes was performed using two techniques: leaching (Cunha et al., 2009), in which the isotope ratios are obtained from the measurement of partial or bioavailable $\mathrm{Pb}$, and total dissolution method (Rocha, 2011). Determination of the partial $\mathrm{Pb}$ isotope ratios (leaching method) was performed at the Analytical Geochemistry Laboratory from the Geosciences Institute of the Universidade Estadual de Campinas (UNICAMP). To $1.0 \mathrm{~g}$ of each sample, placed in a $50 \mathrm{~mL}$ centrifuge tube, was added $10 \mathrm{~mL}$ of nitric acid (HNO) $\left(0.1 \mathrm{~mol} \mathrm{~L}^{-1}\right)$. The samples were leached for 2 hours at a temperature of $85^{\circ}$ Celsius, using a shaking water bath equipment (Dubnoff). After cooling, the samples were centrifuged at $2000 \mathrm{rpm}$ for 10 minutes and then the supernatant was removed by pipetting and transferred to a $15 \mathrm{~mL}$ centrifuge tube. Duplicates were obtained every ten samples. On the other hand, the process of total dissolution of the sediment samples was performed in Actlabs (Activation Laboratories Ltd., Canada). Aliquots of the same samples were submitted to the leach method. The procedure involved the use of hydrofluoric acid (HF) and hydrochloric acid $(\mathrm{HCl})$. In both techniques (leaching and total dissolution) the $\mathrm{Pb}$ isotopes $\left({ }^{204} \mathrm{~Pb},{ }^{206} \mathrm{~Pb},{ }^{207} \mathrm{~Pb}\right.$, ${ }^{208} \mathrm{~Pb}$ ) were determined using a Mass Spectrometer.

The values obtained by total dissolution were read with an Inductively Coupled Plasma Mass Spectrometer (ICPMS) equipped with CCT (Collision Cell Technology). 


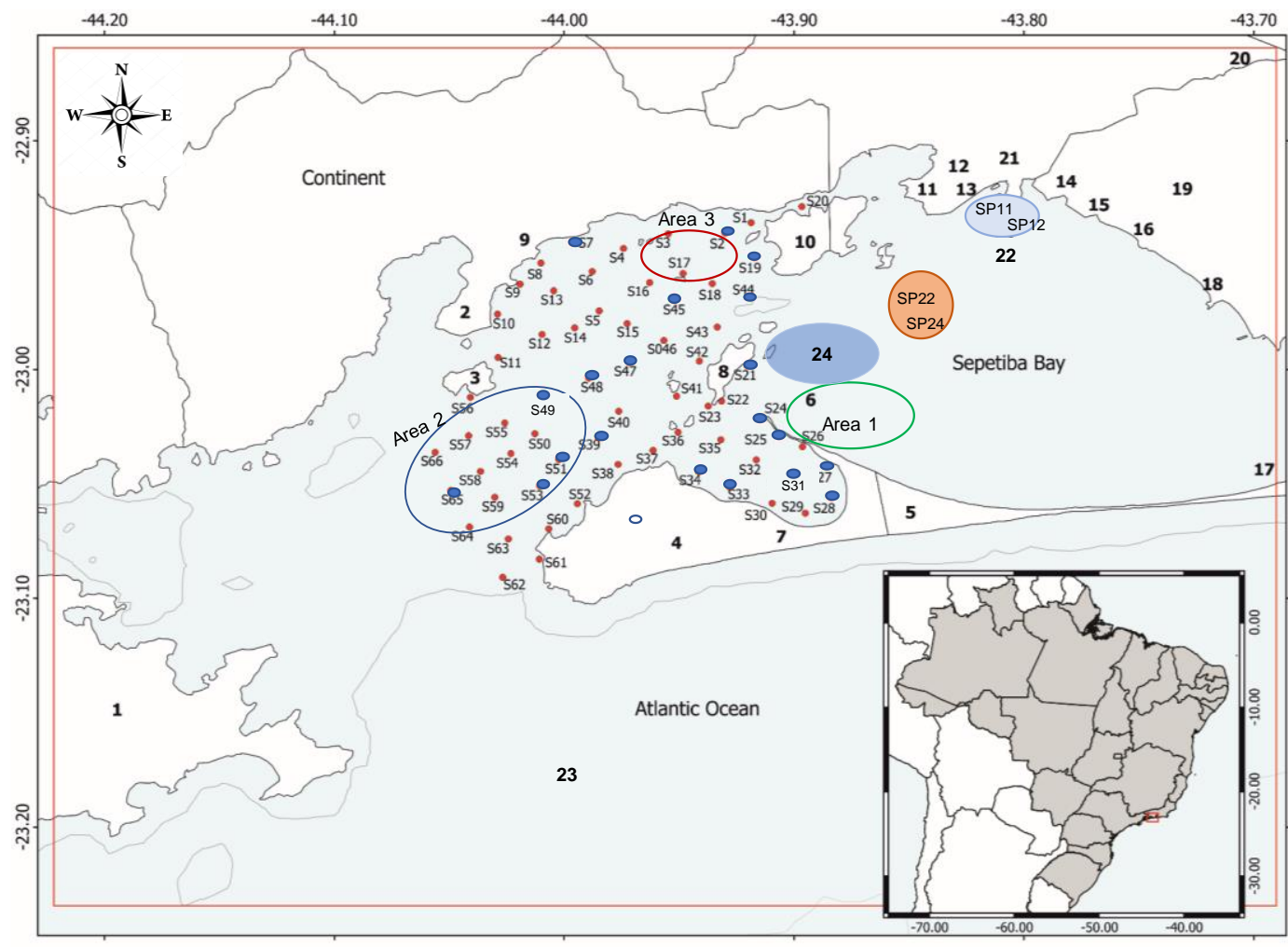

A.

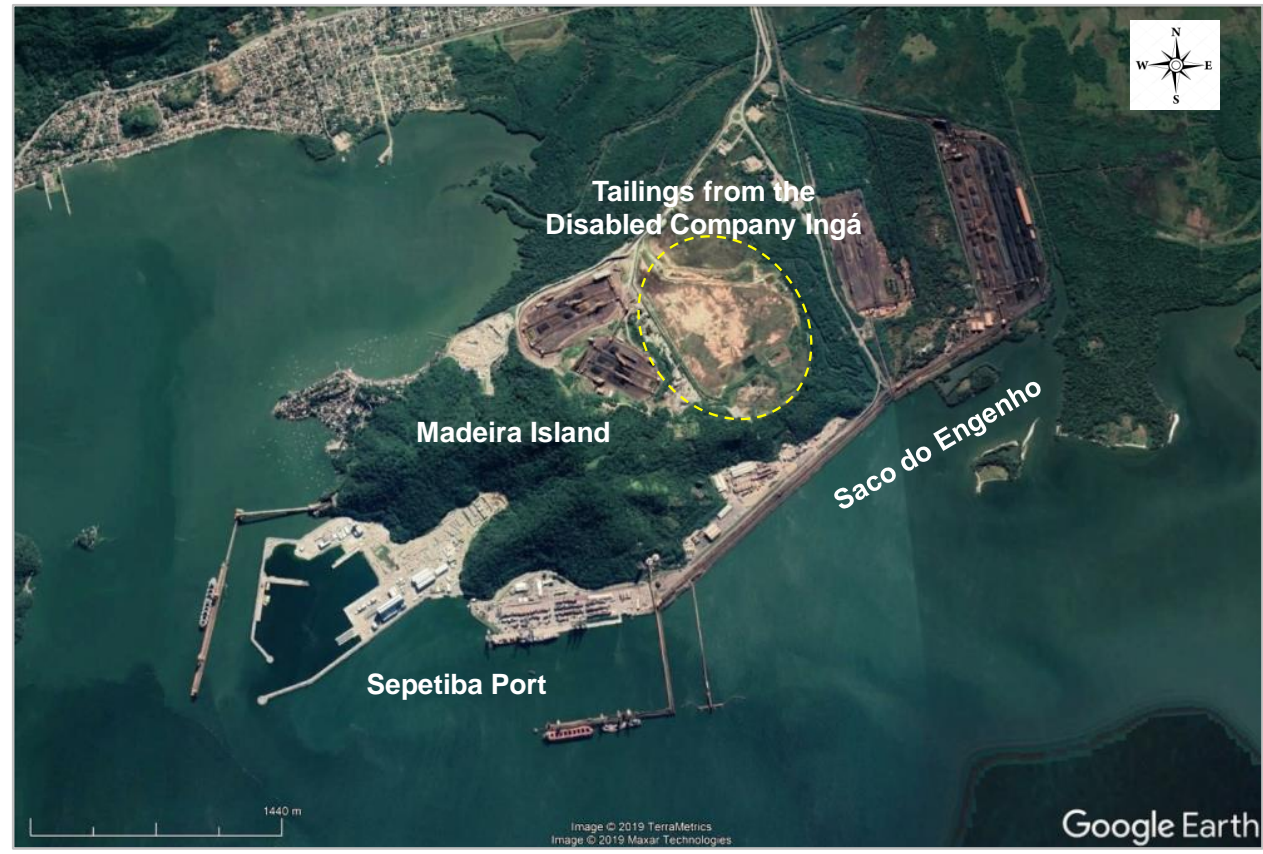

B.

Fig. 1. A. Study area (Sepetiba Bay, RJ, Brazil) with the location of the stations where the superficial sediment samples were collected. The samples analyzed for $\mathrm{Pb}$ concentration and $\mathrm{Pb}$ isotopic signatures are represented in blue and red, respectively. $\mathrm{B}$. Location of the ore residues of the deactivated company Mercantil Ingá (site 11 in the upper panel; adapted from Google Earth). Legend: 1- Ilha Grande; 2- Mangaratiba; 3 - Guaíba Island (Port terminal); 4 - Ponta da Marambaia; 5 - Marambaia Barrier Island; 6- Ponta da Pombeba; 7 Marambaia Bay; 8 - Jaguanum Island; 9- Saí River; 10- Itacuruçá Island; 11- Madeira Island (Itaguaí / Sepetiba Port); 12- Company Mercantil Ingá (deactivated industry - metallic tailings); 13 - Saco do Engenho; 14- Guarda River; 15- São Francisco Canal; 16 - Guandú Channel; 17 - Barra de Guaratiba; 18 - Sepetiba town; 19 - Santa Cruz town; 20 - Nova Iguaçu town; 21 - Itaguaí; 22 - Dredging area of the Sepetiba Port; 23 - Current area of sediment dredging of the Sepetiba Port; 24- Ancient area of dredged sediment from the Sepetiba Port; SP11 and SP12 (end member A) (Cunha et al., 2009); SP22 and SP24 (end member B) (Cunha et al., 2009). Areas 1, 2 and 3 signaled by ellipses are the alternative places for discarding dredged material from the channel giving access to the port area, as suggested by the company Docas (Ecologus, 2008). 
doi: $10.12957 /$ jse.2019.45269

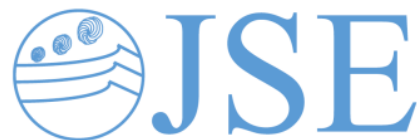

RESEARCH PAPER

Tab. 1. Total (complete dissolution technique) and partial (leaching technique) concentrations of Pb determined in surface sediment samples from the western sector of Sepetiba Bay. Legend. SD - standard deviation.

\begin{tabular}{|c|c|c|c|c|}
\hline Station & Latitude & Longitude & Pb Total $\left(\mu g g^{-1}\right)$ & Pb Partial $\left(\mu \mathrm{g} \mathrm{g}^{-1}\right)$ \\
\hline S01 & 2256.146 & 4355.125 & 25.0 & - \\
\hline S02 & 2256.420 & 4355.802 & 25.0 & 2.9 \\
\hline S03 & 2256.439 & 4357.288 & 22.0 & 0.1 \\
\hline S04 & 2256.821 & 4358.453 & 22.0 & 0.0 \\
\hline S05 & 2258.460 & 4359.089 & 21.0 & 0.0 \\
\hline S06 & 2257.427 & 4359.271 & 19.0 & 0.0 \\
\hline S07 & 2256.666 & 4359.779 & 25.0 & 2.8 \\
\hline S08 & 2257.205 & 4400.611 & 26.0 & 0.3 \\
\hline S09 & 2257.759 & 4401.154 & 23.0 & 0.0 \\
\hline S10 & 2258.544 & 4401.742 & 21.0 & 0.0 \\
\hline S11 & 2259.681 & 4401.729 & 18.0 & 0.0 \\
\hline S12 & 2259.076 & 4400.581 & 19.0 & 0.0 \\
\hline S13 & 2257.932 & 4400.277 & 22.0 & 0.0 \\
\hline S14 & 2258.905 & 4359.729 & 13.0 & 0.0 \\
\hline S15 & 2258.793 & 4358.361 & 21.0 & 0.0 \\
\hline S16 & 2257.717 & 4357.773 & 23.0 & 0.0 \\
\hline S17 & 2257.478 & 4356.900 & 12.0 & 0.0 \\
\hline S18 & 2257.743 & 4356.137 & 33.0 & 0.1 \\
\hline S19 & 2257.056 & 4355.037 & 21.0 & 4.6 \\
\hline S20 & 2255.725 & 4353.800 & 35.0 & 0.0 \\
\hline S21 & 2259.894 & 4355.217 & 24.0 & 1.6 \\
\hline S22 & 2300.826 & 4355.895 & 18.0 & 0.0 \\
\hline S23 & 2300.956 & 4356.243 & 20.0 & 0.0 \\
\hline S24 & 2301.264 & 4354.838 & 21.0 & 4.0 \\
\hline S25 & 2301.740 & 4354.390 & 28.0 & 3.9 \\
\hline S26 & 2302.022 & 4353.784 & 19.0 & 0.4 \\
\hline S27 & 2302.535 & 4353.161 & 26.0 & 0.7 \\
\hline S28 & 2303.348 & 4353.041 & 29.0 & 5.2 \\
\hline S29 & 2303.766 & 4353.710 & 23.0 & 0.0 \\
\hline $\mathrm{S} 30$ & 2303.503 & 4354.575 & 22.0 & 0.1 \\
\hline S31 & 2302.847 & 4354.111 & 21.0 & 1.3 \\
\hline S32 & 2302.366 & 4354.989 & 19.0 & 0.1 \\
\hline S33 & 2303.082 & 4355.682 & 23.0 & 2.5 \\
\hline S34 & 2302.676 & 4356.491 & 17.0 & 2.0 \\
\hline S35 & 2301.839 & 4355.915 & 34.0 & 0.0 \\
\hline S36 & 2301.643 & 4357.031 & 19.0 & 0.0 \\
\hline S37 & 2302.118 & 4357.683 & 21.0 & 0.0 \\
\hline S38 & 2302.485 & 4358.596 & 27.0 & 0.0 \\
\hline S39 & 2301.772 & 4359.112 & 16.0 & 2.0 \\
\hline S40 & 2301.092 & 4358.580 & 21.0 & 0.3 \\
\hline S41 & 2300.697 & 4357.071 & 8.0 & 0.0 \\
\hline S42 & 2259.775 & 4356.476 & 23.0 & 0.0 \\
\hline S43 & 2258.885 & 4356.008 & 15.0 & 0.0 \\
\hline S44 & 2258.085 & 4355.148 & 21.0 & 0.7 \\
\hline S45 & 2258.178 & 4357.143 & 21.0 & 0.5 \\
\hline S46 & 2259.235 & 4357.401 & 22.0 & 0.1 \\
\hline S47 & 2259.804 & 4358.303 & 19.0 & 1.9 \\
\hline S48 & 2300.220 & 4359.361 & 19.0 & 0.6 \\
\hline S49 & 2300.718 & 4400.620 & 13.0 & 1.1 \\
\hline $\mathrm{S} 50$ & 2301.681 & 4400.767 & 11.0 & 0.0 \\
\hline S51 & 2302.353 & 4400.140 & 14.0 & 3.3 \\
\hline S52 & 2303.516 & 4359.659 & 5.0 & 0.0 \\
\hline S53 & 2303.050 & 4400.640 & 22.0 & 0.6 \\
\hline S54 & 2302.200 & 4401.393 & 21.0 & 0.0 \\
\hline
\end{tabular}


Table 1 (cont.) - Total (complete dissolution technique) and partial (leaching technique) concentrations of Pb determined in surface sediment samples from the western sector of Sepetiba Bay. Legend. SD - standard deviation.

\begin{tabular}{|l|c|c|c|c|}
\hline Station & Latitude & Longitude & Pb Total $\left(\boldsymbol{\mu g} \mathbf{g}^{-\mathbf{1}}\right)$ & $\mathbf{P b}$ Partial $\left(\boldsymbol{\mu} \mathbf{g} \mathbf{~ g}^{-\mathbf{1}}\right)$ \\
\hline S55 & 2301.399 & 4401.554 & 18.0 & 0.0 \\
\hline S56 & 2300.726 & 4402.449 & 9.0 & 0.0 \\
\hline S57 & 2301.730 & 4402.498 & 28.0 & 0.0 \\
\hline S58 & 2302.669 & 4402.187 & 20.0 & 0.0 \\
\hline S59 & 2303.346 & 4401.814 & 14.0 & 0.0 \\
\hline S60 & 2304.173 & 4400.404 & 13.0 & 0.0 \\
\hline S61 & 2304.972 & 4400.653 & 26.0 & 0.0 \\
\hline S62 & 2305.446 & 4401.608 & 10.0 & 0.0 \\
\hline S63 & 2304.440 & 4401.459 & 15.0 & 0.0 \\
\hline S64 & 2304.126 & 4402.473 & 11.0 & 1.7 \\
\hline S65 & 2303.169 & 4402.959 & 22.0 & 0.0 \\
\hline S66 & 2302.168 & 4403.371 & 11.0 & 5.2 \\
\hline Maximum & --- & --- & 35.0 & 0.0 \\
\hline Minimum & --- & --- & 5.0 & $0.7 \pm 1.3$ \\
\hline Mean +SD & --- & -- & $20.1 \pm 6.0$ & \\
\hline
\end{tabular}

The determination of the isotopic composition was performed only in the 21 samples (red symbols in Figure 1) with $\mathrm{Pb}$ concentrations, determined by the leaching method, above $0.5 \mu \mathrm{g} \mathrm{g} \mathrm{g}^{-1}$ (partial $\mathrm{Pb}$ content), due to the detection limit of the equipment (ICP-MS).

For comparative purposes, 19 of these samples were also selected for determination of the isotopic composition by the total dissolution method (blue symbols in Figure 1). The reference materials NIST 981 (Common Lead Isotopic Standard) and NIST 1648 (Urban Particulate Matter) were used for quality control.

\section{Results and Discussion}

\subsection{Pb isotope ratios obtained by the total dissolution technique}

Total and partial concentrations of $\mathrm{Pb}$ are displayed in Table 1 whereas the $\mathrm{Pb}$ isotope ratios, obtained by the total dissolution technique, are presented in Table 2 , as well as the minimum, maximum, mean and standard deviation values.

The increasing order distribution of the isotope ratios ${ }^{206} \mathrm{~Pb} /{ }^{207} \mathrm{~Pb}$ allowed the identification of possible signatures of lead isotopes, named end member 1, end member 2 and end member 3 (Fig. 2). These results were compared to those obtained by correlations between the isotope ratios ${ }^{206} \mathrm{~Pb} / 204 \mathrm{~Pb}$ versus ${ }^{207} \mathrm{~Pb} / 204 \mathrm{~Pb}$ and ${ }^{208} \mathrm{~Pb} / 206 \mathrm{~Pb}$ versus ${ }^{206} \mathrm{~Pb} / 207 \mathrm{~Pb}$, and allowed the differentiation of three possible groups of samples with different ranges of $\mathrm{Pb}$ isotope ratios (Fig. 3), similar to those shown in Fig. 2.

End member 1 is composed by samples S02, S39, S49, S51 and S53; end member 2 includes samples S07, S19, S24, S28,
S31, S33, S34, S44, S45 and S48, and; end member 3 encompasses the samples S21, S25, S27 and S47 (Fig. 3).

The values of ${ }^{206} \mathrm{~Pb} /{ }^{204} \mathrm{~Pb}$ and ${ }^{207} \mathrm{~Pb} /{ }^{204} \mathrm{~Pb}$ ratios ranged from 18.10 to 20.23 and from 15.51 to 16.07 , respectively (Fig. 3). End member 1 presented values ranging from 18.10

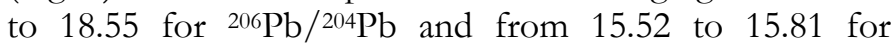
${ }^{207} \mathrm{~Pb} /{ }^{204} \mathrm{~Pb}$. End member 2 displayed values varying between 18.39 and 18.90 for ${ }^{206} \mathrm{~Pb} / 204 \mathrm{~Pb}$ and between 15.51 and 15.79 for ${ }^{207} \mathrm{~Pb} /{ }^{204} \mathrm{~Pb}$. End member 3 showed values for ${ }^{206} \mathrm{~Pb} /{ }^{204} \mathrm{~Pb}$ ranging between 19.33 and 20.23 and for ${ }^{207} \mathrm{~Pb} /{ }^{204} \mathrm{~Pb}$ oscillating between 15.71 and 16.07 .

${ }^{208} \mathrm{~Pb} / 206 \mathrm{~Pb}$ and ${ }^{206} \mathrm{~Pb} / 207 \mathrm{~Pb}$ ratios ranged between 2.08 2.21 and 1.16-1.26, respectively (Fig. 3). End member 1 presented values of $208 \mathrm{~Pb} / 206 \mathrm{~Pb}$ and $206 \mathrm{~Pb} / 207 \mathrm{~Pb}$ ranging between 2.09-2.12 and 1.16-1.17, respectively. For end member 2 , the ratios of $208 \mathrm{~Pb} / 206 \mathrm{~Pb}$ and ${ }^{206} \mathrm{~Pb} /{ }^{207} \mathrm{~Pb}$ varied between 2.08-2.11 and 1.18-1.20, respectively. End member 3 presented values between $2.11-2.21$ for ${ }^{208} \mathrm{~Pb} /{ }^{206} \mathrm{~Pb}$ and $1.21-1.26$ for ${ }^{206} \mathrm{~Pb} / 207 \mathrm{~Pb}$.

The isotopic signatures of $\mathrm{Pb}\left({ }^{206} \mathrm{~Pb} /{ }^{207} \mathrm{~Pb}\right)$ determined by the total dissolution technique, allowed to observe that: end member 1 (stations S02, S39, S49, S51 and S53), with the smallest ${ }^{206} \mathrm{~Pb} /{ }^{207} \mathrm{~Pb}$ ratios (from 1.163 to 1.173 ) was found in stations of the outer region of the study area and near Itacuruçá Island (lighter color in Fig. 4); end member 2 (samples S07, S19, S24, S28, S31, S33, S34, S44, S45 and $\mathrm{S} 48$ ), with intermediate values of $206 \mathrm{~Pb} / 207 \mathrm{~Pb}$ ratios (from 1.183 to 1.198 ), was found in most of the study area (see the orange-colored area in Fig. 4); and end member 3 (S21, S25, $\mathrm{S} 27$ and S47), with the highest ${ }^{206} \mathrm{~Pb} /{ }^{207} \mathrm{~Pb}$ ratios (from 1.215 to 1.259 ), was located in specific locations (marked by the reddish coloration in Fig. 4). 


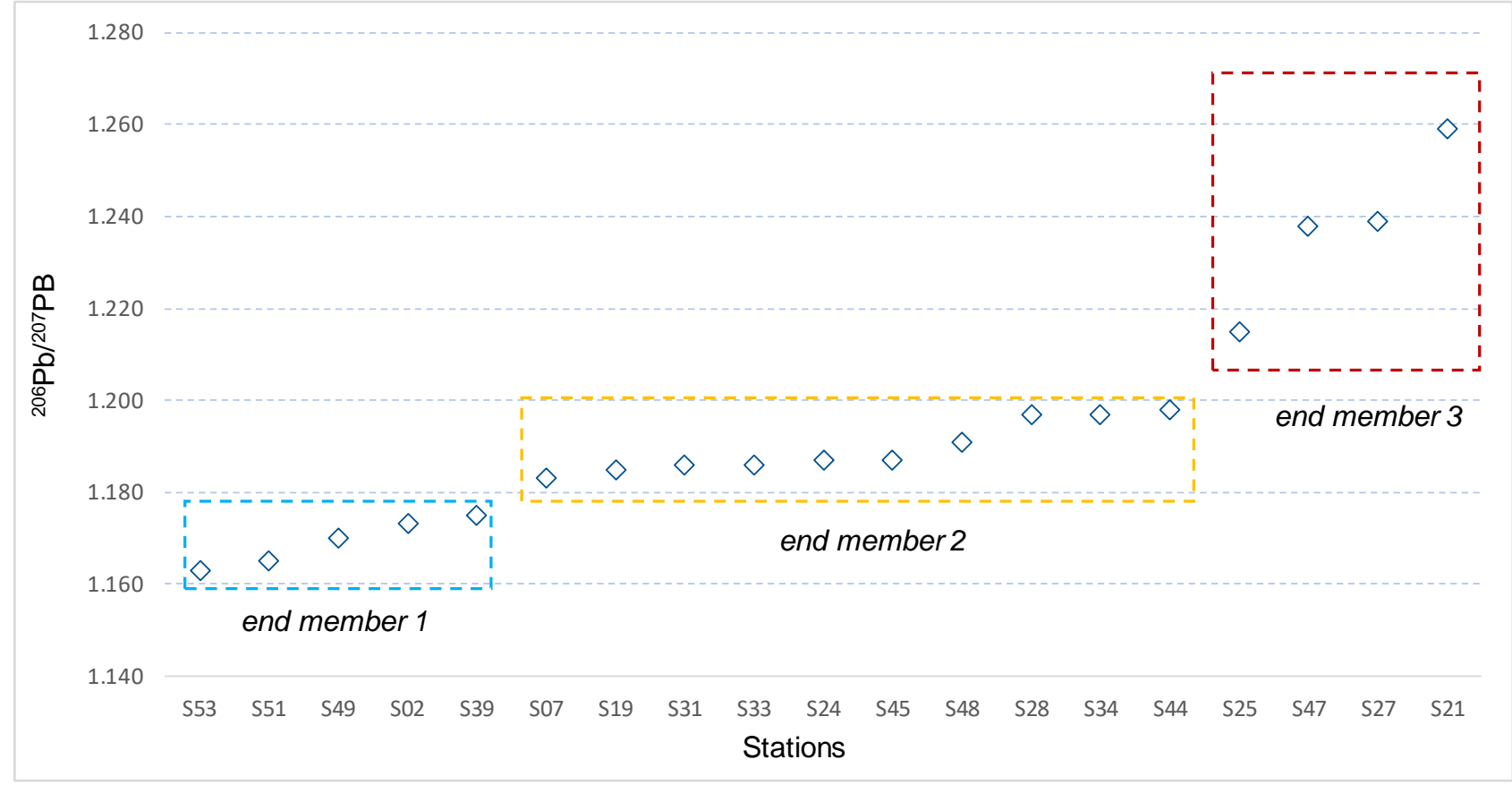

Fig. 2. Identification of the isotopic signatures of $\mathrm{Pb}$ based on ${ }^{206} \mathrm{~Pb} /{ }^{207} \mathrm{~Pb}$ values determined by the total digestion technique.

Tab. 2. $\mathrm{Pb}$ isotope ratios obtained by total dissolution of the sediment samples collected in the western sector of Sepetiba Bay. Location in Figure 1.

\begin{tabular}{|c|c|c|c|c|c|c|c|}
\hline Station & ${ }^{206} \mathrm{~Pb} /{ }^{204} \mathrm{~Pb}$ & ${ }^{207} \mathrm{~Pb} /{ }^{204} \mathrm{~Pb}$ & ${ }^{208} \mathrm{~Pb} /{ }^{204} \mathrm{~Pb}$ & ${ }^{206} \mathrm{~Pb} /{ }^{207} \mathrm{~Pb}$ & ${ }^{208} \mathrm{~Pb} /{ }^{206} \mathrm{~Pb}$ & ${ }^{207} \mathrm{~Pb} /{ }^{206} \mathrm{~Pb}$ & ${ }^{208} \mathrm{~Pb} /{ }^{207} \mathrm{~Pb}$ \\
\hline S02 & 18.546 & 15.816 & 38.995 & 1.173 & 2.103 & 0.853 & 2.466 \\
\hline S07 & 18.649 & 15.762 & 39.341 & 1.183 & 2.110 & 0.845 & 2.496 \\
\hline S19 & 18.387 & 15.511 & 38.696 & 1.185 & 2.104 & 0.844 & 2.495 \\
\hline S21 & 20.229 & 16.070 & 44.741 & 1.259 & 2.212 & 0.794 & 2.784 \\
\hline S24 & 18.520 & 15.596 & 38.619 & 1.187 & 2.085 & 0.842 & 2.476 \\
\hline S25 & 19.335 & 15.908 & 40.898 & 1.215 & 2.115 & 0.823 & 2.571 \\
\hline S27 & 19.649 & 15.854 & 41.486 & 1.239 & 2.111 & 0.807 & 2.617 \\
\hline S28 & 18.898 & 15.794 & 39.787 & 1.197 & 2.105 & 0.836 & 2.519 \\
\hline S31 & 18.554 & 15.647 & 38.928 & 1.186 & 2.098 & 0.843 & 2.488 \\
\hline S33 & 18.587 & 15.669 & 38.846 & 1.186 & 2.090 & 0.843 & 2.479 \\
\hline S34 & 18.769 & 15.678 & 39.117 & 1.197 & 2.084 & 0.835 & 2.495 \\
\hline S39 & 18.245 & 15.529 & 38.332 & 1.175 & 2.101 & 0.851 & 2.468 \\
\hline S44 & 18.789 & 15.683 & 39.433 & 1.198 & 2.099 & 0.835 & 2.514 \\
\hline S45 & 18.624 & 15.689 & 39.159 & 1.187 & 2.103 & 0.842 & 2.496 \\
\hline S47 & 19.460 & 15.713 & 41.585 & 1.238 & 2.137 & 0.807 & 2.647 \\
\hline S48 & 18.629 & 15.645 & 39.216 & 1.191 & 2.105 & 0.840 & 2.507 \\
\hline S49 & 18.455 & 15.777 & 38.667 & 1.170 & 2.095 & 0.855 & 2.451 \\
\hline S51 & 18.245 & 15.659 & 38.640 & 1.165 & 2.118 & 0.858 & 2.468 \\
\hline S53 & 18.104 & 15.566 & 38.470 & 1.163 & 2.125 & 0.860 & 2.471 \\
\hline Minimum. & 18.104 & 15.511 & 38.332 & 1.1631 & 2.084 & 0.794 & 2.451 \\
\hline Maximum & 20.229 & 16.070 & 44.741 & 1.2588 & 2.212 & 0.860 & 2.784 \\
\hline Mean +SD & $18.772 \pm 0.537$ & $15.714 \pm 0.136$ & $39.629 \pm 1.566$ & $1.1945 \pm 0.0262$ & $2.11 \pm 0.028$ & $0.838 \pm 0.018$ & $2.52 \pm 0.082$ \\
\hline
\end{tabular}



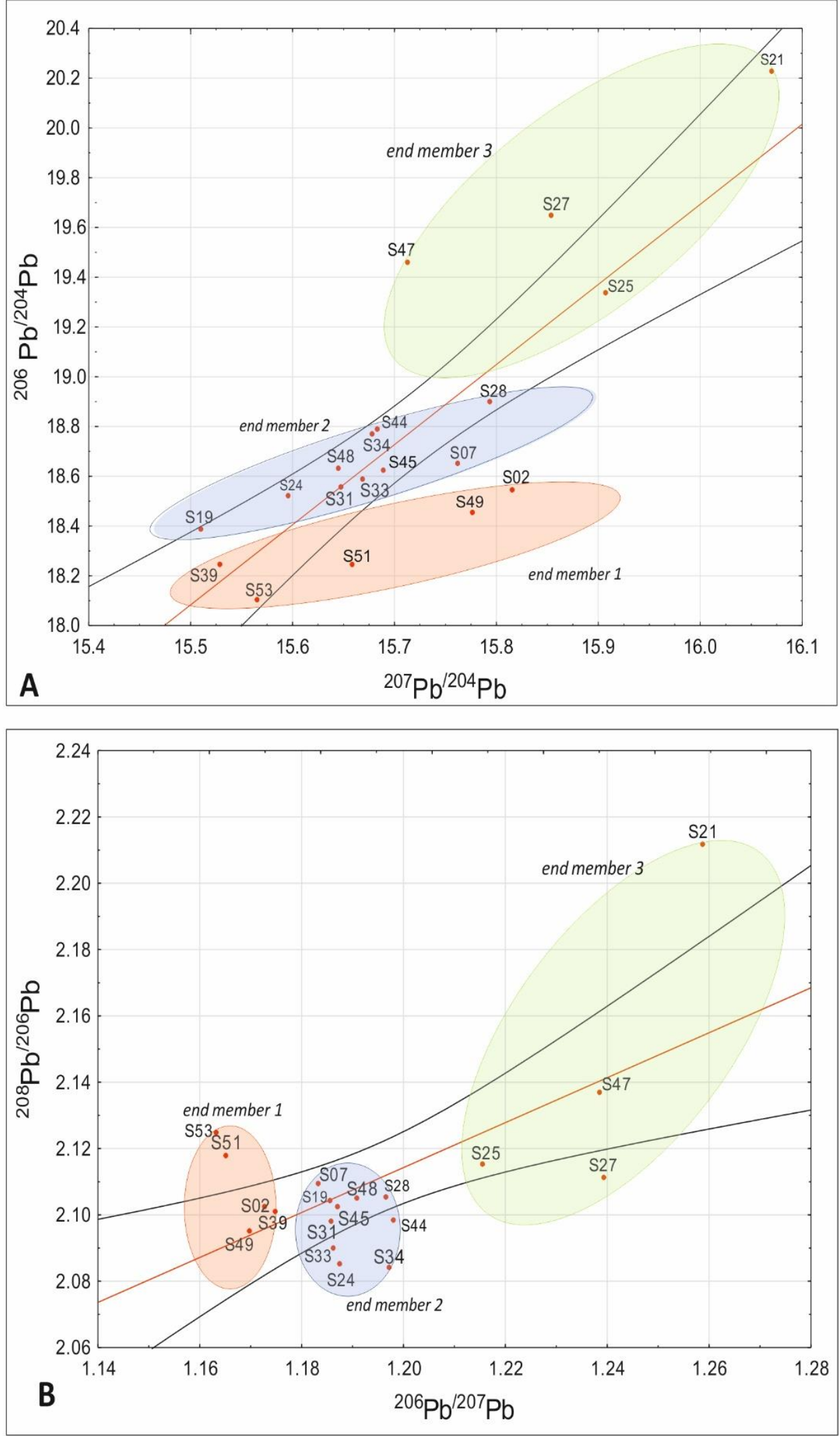

Fig. 3. Correlations between $\mathrm{Pb}$ isotope ratios obtained by total dissolution (location in Fig. 1): (A) ${ }^{206} \mathrm{~Pb} /{ }^{204} \mathrm{~Pb}$ versus ${ }^{207} \mathrm{~Pb} /{ }^{204} \mathrm{~Pb}$ and (B) ${ }^{208} \mathrm{~Pb} /{ }^{206} \mathrm{~Pb}$ versus ${ }^{206} \mathrm{~Pb} /{ }^{207} \mathrm{~Pb}$. End members are separated by circles of different colors (red - end member 1; blue - end member 2; green - end member 3). 


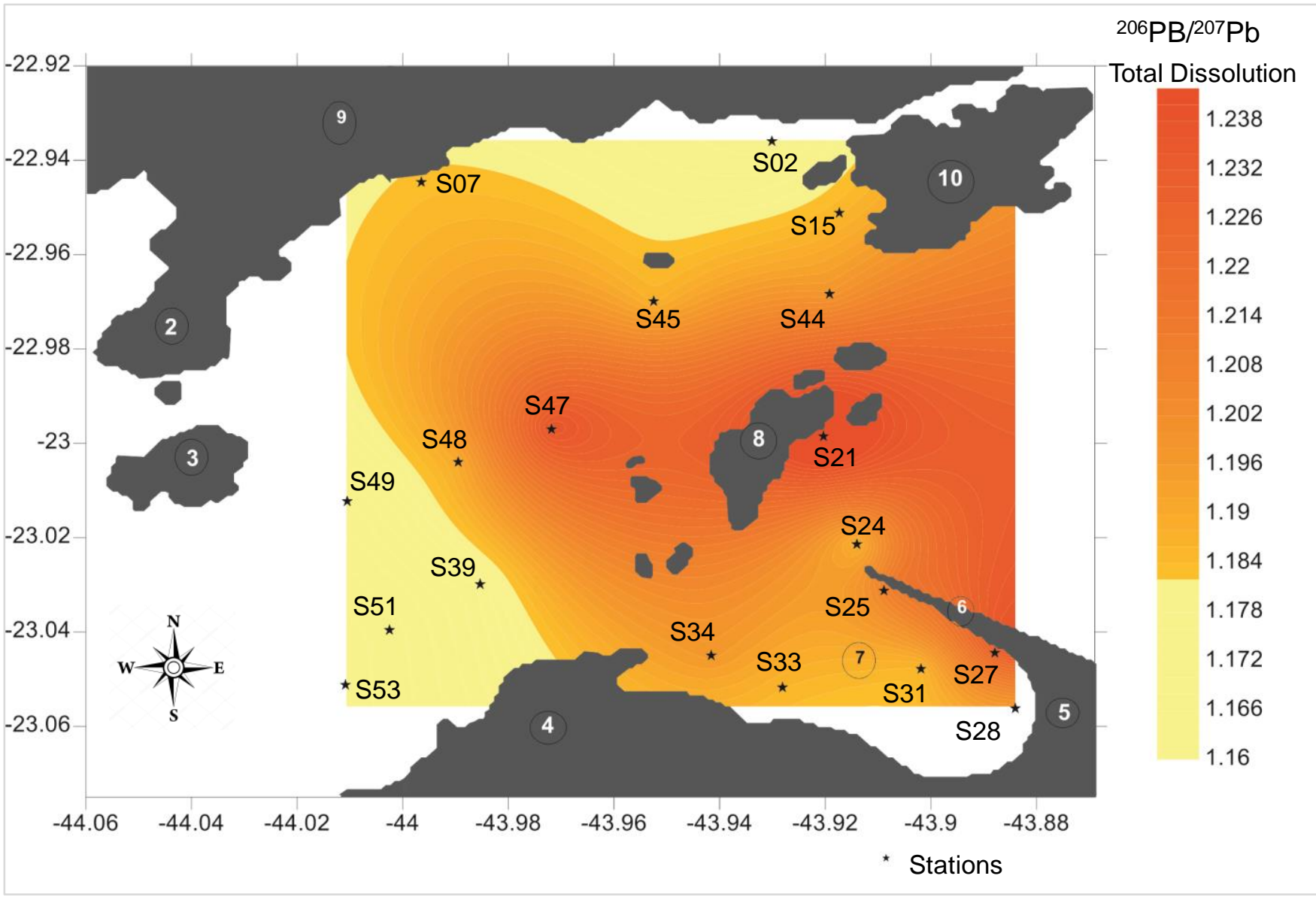

Fig.4. Spatial distribution of the isotopic signatures of $\mathrm{Pb}\left({ }^{206} \mathrm{~Pb} /{ }^{207} \mathrm{~Pb}\right)$ obtained by the total dissolution method. 2- Mangaratiba; 3- Ilha Guaíba (Port terminal); 4- Ponta da Marambaia; 5- Marambaia Barrier Island; 6- Ponta da Pombeba; 7- Marambaia Bay; 8- Jaguanum Island; 9- Saí River; 10- Itacuruçá Island.

However, the three possible groups (end members 1 to 3 ), identified through the correlations between ${ }^{206} \mathrm{~Pb} / 204 \mathrm{~Pb}$ versus ${ }^{207} \mathrm{~Pb} /{ }^{204} \mathrm{~Pb}$ and ${ }^{208} \mathrm{~Pb} / 206 \mathrm{~Pb}$ versus ${ }^{206} \mathrm{~Pb} /{ }^{207} \mathrm{~Pb}$, were not clearly separated when these values were compared to those obtained in the central-eastern sector of Sepetiba Bay by Rocha (2011), that analyzed 21 samples of surface sediments using the same technique of total dissolution. By integrating the results from Rocha (2011) with those presented in this paper (a total of 40 samples), a different picture of the distribution of the isotope ratios emerges, with a single signature, called end member F (Fig. 5).

In a previous study carried out in the northern and central-eastern sector of Sepetiba Bay, Rocha (2011) identified an end member $C$ with an isotopic signature between 1.174 and 1.21 determined by the total dissolution method (Fig. 5). These values are similar to those from end member $A$ of Rocha (2011), determined by the leaching technique, and corresponding to stations SP11 and SP12 (Fig. 1). The author related these values to industrial sources, namely from the decommissioned Mercantil Ingá mining industry tailings area, in addition to gasoline and domestic and industrial effluents that reach Sepetiba Bay. Thus, the isotopic signature of ${ }^{206} \mathrm{~Pb} / 207 \mathrm{~Pb}$, obtained by total dissolution and described in the present study, can be considered similar to end member C of Rocha (2011), which is related to areas with strong anthropic influence (Fig. 5).

\subsection{Pb isotope ratios obtained by the leaching technique}

Isotopic ratios obtained by leaching are shown in Table 3 , as well as the minimum, maximum, mean and standard deviation values.

Initially, the increasing order of ${ }^{206} \mathrm{~Pb} /{ }^{207} \mathrm{~Pb}$ ratios allowed the identification of possible signatures of $\mathrm{Pb}$ isotopes, named as end members 1-4 (Fig. 6): end member 1 composed by sample $\mathrm{S} 51$; end member 2 includes samples $\mathrm{S} 28$, S31, S33; end member 3 composed by samples S25, S27, S58, S24, S02, S21, S44, S47 and S48; and end member 4 encompassing samples S07, S19 S45, S49, S53 and S65. Samples S34 and S39 plot between end member 1 and end member 2 and may represent a mixture of both.

These results were compared to those obtained by correlations between the isotope ratios ${ }^{206} \mathrm{~Pb} / 204 \mathrm{~Pb}$ versus ${ }^{207} \mathrm{~Pb} / 204 \mathrm{~Pb}$ (Fig. $7 \mathrm{~A}$ ) and ${ }^{208} \mathrm{~Pb} / 206 \mathrm{~Pb}$ versus ${ }^{206} \mathrm{~Pb} /{ }^{207} \mathrm{~Pb}$ (Fig. 7B), which also allowed the differentiation of four groups of stations. 
Tab. 3. Isotopic ratios of $\mathrm{Pb}$ obtained by leaching in sediment samples collected in the western sector of Sepetiba Bay. Location in Figure 1

\begin{tabular}{|c|c|c|c|c|c|c|c|c|}
\hline Stations & ${ }^{206} \mathrm{~Pb} / 204 \mathrm{~Pb}$ & ${ }^{207} \mathrm{~Pb} / 204 \mathrm{~Pb}$ & ${ }^{208} \mathrm{~Pb} / 204 \mathrm{~Pb}$ & ${ }^{207} \mathrm{~Pb} / 206 \mathrm{~Pb}$ & ${ }^{208} \mathrm{~Pb} / 206 \mathrm{~Pb}$ & ${ }^{208} \mathrm{~Pb} / 207 \mathrm{~Pb}$ & ${ }^{206} \mathrm{~Pb} / 207 \mathrm{~Pb}$ & ${ }^{204} \mathrm{~Pb} / 206 \mathrm{~Pb}$ \\
\hline S02 & 18.445 & 15.645 & 38.434 & 0.848 & 2.084 & 2.457 & 1.179 & 0.054 \\
\hline S07 & 18.480 & 15.644 & 38.482 & 0.847 & 2.082 & 2.460 & 1.181 & 0.054 \\
\hline S19 & 18.505 & 15.675 & 38.372 & 0.847 & 2.074 & 2.448 & 1.181 & 0.054 \\
\hline S21 & 18.502 & 15.694 & 38.247 & 0.848 & 2.067 & 2.437 & 1.179 & 0.054 \\
\hline S24 & 18.500 & 15.700 & 38.342 & 0.849 & 2.073 & 2.442 & 1.178 & 0.054 \\
\hline S25 & 18.463 & 15.684 & 38.499 & 0.850 & 2.085 & 2.455 & 1.177 & 0.054 \\
\hline S27 & 18.433 & 15.660 & 38.547 & 0.850 & 2.091 & 2.461 & 1.177 & 0.054 \\
\hline S28 & 18.360 & 15.622 & 38.542 & 0.851 & 2.099 & 2.467 & 1.175 & 0.054 \\
\hline S31 & 18.398 & 15.658 & 38.527 & 0.851 & 2.094 & 2.461 & 1.175 & 0.054 \\
\hline S33 & 18.376 & 15.637 & 38.476 & 0.851 & 2.094 & 2.461 & 1.175 & 0.054 \\
\hline S34 & 18.431 & 15.670 & 38.600 & 0.850 & 2.094 & 2.463 & 1.176 & 0.054 \\
\hline S39 & 18.477 & 15.706 & 38.639 & 0.850 & 2.091 & 2.460 & 1.176 & 0.054 \\
\hline S44 & 18.471 & 15.669 & 38.571 & 0.848 & 2.088 & 2.462 & 1.179 & 0.054 \\
\hline S45 & 18.502 & 15.665 & 38.541 & 0.847 & 2.083 & 2.460 & 1.181 & 0.054 \\
\hline S47 & 18.515 & 15.698 & 38.496 & 0.848 & 2.079 & 2.452 & 1.179 & 0.054 \\
\hline S48 & 18.524 & 15.704 & 38.493 & 0.848 & 2.078 & 2.451 & 1.180 & 0.054 \\
\hline S49 & 18.516 & 15.675 & 38.312 & 0.847 & 2.069 & 2.444 & 1.181 & 0.054 \\
\hline S51 & 18.604 & 15.664 & 38.098 & 0.842 & 2.048 & 2.432 & 1.188 & 0.054 \\
\hline S53 & 18.500 & 15.661 & 38.259 & 0.847 & 2.068 & 2.443 & 1.181 & 0.054 \\
\hline S58 & 18.460 & 15.684 & 38.500 & 0.850 & 2.086 & 2.455 & 1.177 & 0.054 \\
\hline S65 & 18.479 & 15.641 & 38.232 & 0.846 & 2.069 & 2.444 & 1.181 & 0.054 \\
\hline Minimum & 18.360 & 15.622 & 38.098 & 0.842 & 2.048 & 2.432 & 1.175 & 0.054 \\
\hline Maximum & 18.604 & 15.706 & 38.639 & 0.851 & 2.099 & 2.467 & 1.188 & 0.054 \\
\hline Mean +SD & $18.473 \pm 0.055$ & $15.669 \pm 0.023$ & $38.438 \pm 0.141$ & $0.848 \pm 0.002$ & $2.081 \pm 0.0123$ & $2.453 \pm 0.010$ & $1.179 \pm 0.003$ & $0.054 \pm 0.0002$ \\
\hline
\end{tabular}

The ${ }^{206} \mathrm{~Pb} / 204 \mathrm{~Pb}$ and ${ }^{207} \mathrm{~Pb} / 204 \mathrm{~Pb}$ isotope ratios varied between 18.360 and 18.604 and between 15.622 and 15.706 , respectively (Table 3). The values found for end member 1 were 18.604 for ${ }^{206} \mathrm{~Pb} / 204 \mathrm{~Pb}$ and 15.664 for ${ }^{207} \mathrm{~Pb} / 204 \mathrm{~Pb}$; end member 2 ranged from 18.360 to 18.398 for ${ }^{206} \mathrm{~Pb} / 204 \mathrm{~Pb}$ and from 15.622 to 15.658 for ${ }^{207} \mathrm{~Pb} / 204 \mathrm{~Pb}$; end member 3 varied between 18.433 and 18.524 for ${ }^{206} \mathrm{~Pb} / 204 \mathrm{~Pb}$ and between 15.645 and 15.706 for ${ }^{207} \mathrm{~Pb} / 204 \mathrm{~Pb}$; end member 4 displayed values between 18.479 and 18.516 for ${ }^{206 \mathrm{~Pb}} / 204 \mathrm{~Pb}$ and between 15.641 and 15.675 for ${ }^{207} \mathrm{~Pb} / 204 \mathrm{~Pb}$ (Fig. 7A).

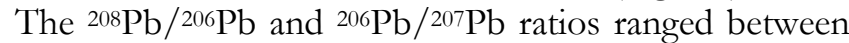
2.048 and 2.099 and between 1.175 and 1.188, respectively (Table 3). The values found for end member 1 was 2.048 for

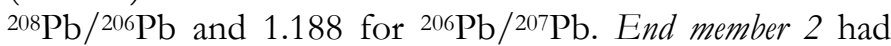
values for ${ }^{208} \mathrm{~Pb} / 206 \mathrm{~Pb}$ ratios between 2.094 and 2.099 and for ${ }^{206 \mathrm{~Pb}} / 207 \mathrm{~Pb}$ of 1.175 . End member 3 ranged from 2.067 to 2.094 for ${ }^{208} \mathrm{~Pb} / 206 \mathrm{~Pb}$ and from 1.176 to 1.180 for ${ }^{206} \mathrm{~Pb} / 207 \mathrm{~Pb}$. End member 4 displayed values between 2.069 and 2.082 for ${ }^{208} \mathrm{~Pb} / 206 \mathrm{~Pb}$ and of 1.181

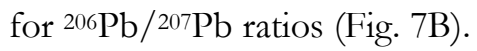

When the isotopic values obtained in this work were compared to those obtained by Cunha et al. (2009) in samples collected in the vicinity of Jaguanum and Itacuruçá islands, and near the rivers' mouths that flow into Sepetiba Bay, by using the same leaching technique, end members 1 to 4 (Figs. 7A, B) were clustered into a single signature, which was named end member F (Fig. 8). Results presented in Figure 8 show that end member $F$ has a signature markedly different from end member $B$ of Cunha et al. (2009) (samples SP22 and SP24; Fig. 1). 


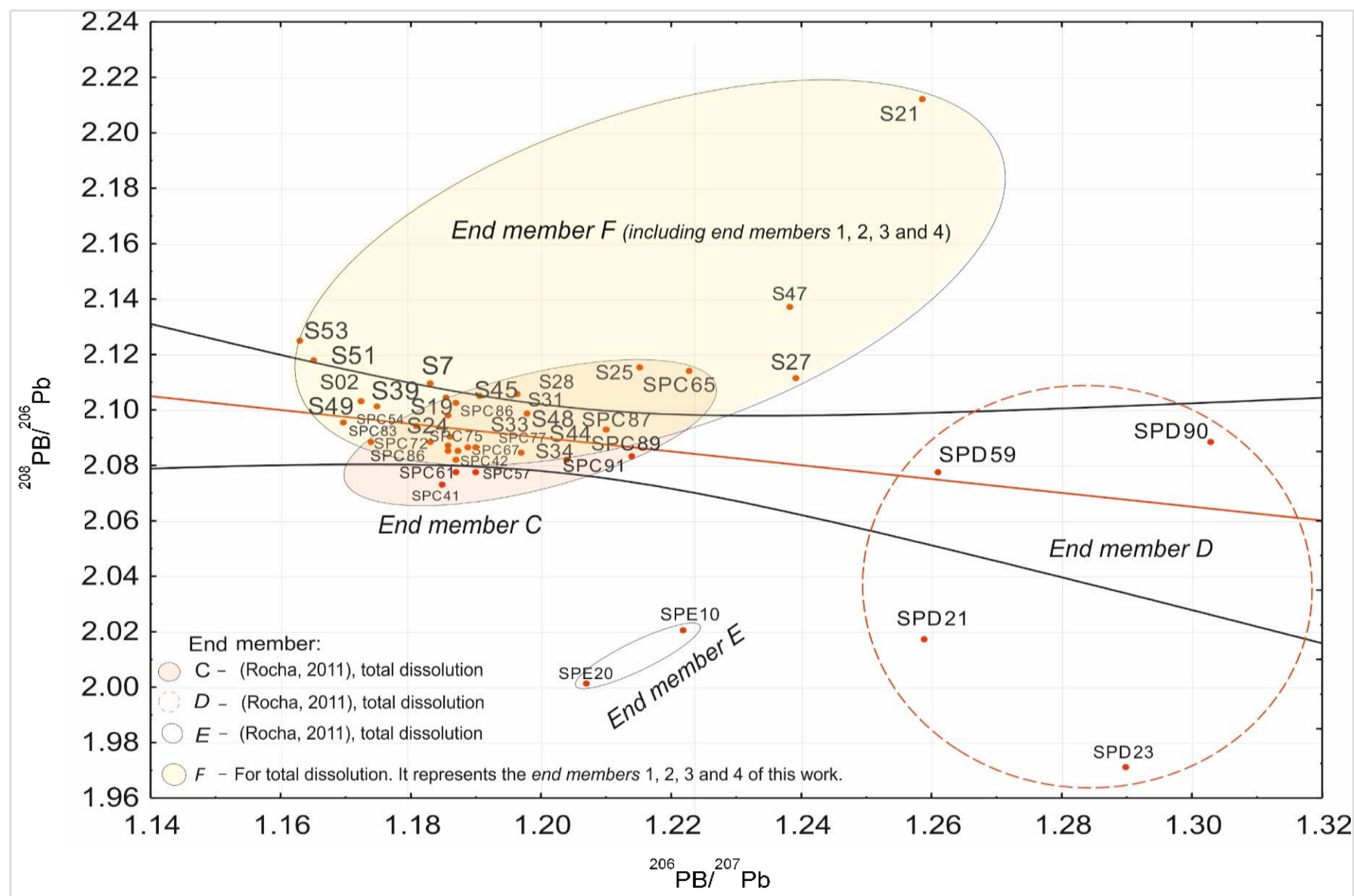

Fig. 5. Correlation between ${ }^{208} \mathrm{~Pb} /{ }^{206} \mathrm{~Pb}$ versus ${ }^{206} \mathrm{~Pb} /{ }^{207} \mathrm{~Pb}$, determined by the total dissolution technique, in the western sector (this study) and in the northern and central-eastern sector of Sepetiba Bay (Rocha, 2011).

Considering the results presented in Fig. 8, of samples from end member F (data of this work), sample S51 exhibits the highest affinity with ${ }^{206 \mathrm{~Pb} /}{ }^{207} \mathrm{~Pb}$ ratios of SP11 and SP12 (Fig. 1) analyzed by Cunha et al. (2009). Stations SP11 and SP12 are located in the region of Saco do Engenho a highly anthropized area. Thus, we can deduce that end member F, including all samples analyzed in the western sector of Sepetiba Bay (present work), contains a clear Pb isotopic anthropogenic signature

${ }^{206} \mathrm{~Pb} /{ }^{207} \mathrm{~Pb}$ ratios, determined by the leaching technique, led to the detection of two possible anomalies (reddish color in Fig. 9): one that prevails in the northern zone of the study area (stations S07, S19, S45), near the Saí River mouth and Itacuruçá Island and a second, more significant, between Guaíba Island (Port terminal) and Ponta da Marambaia (stations S51, S49, S53, S65). These anomalies of the ${ }^{206} \mathrm{~Pb} /{ }^{207} \mathrm{~Pb}$ ratios are also evidenced when the isotopic ratios obtained by both methods, total dissolution and leaching, are compared (Anomalies 1 and 2; Fig. 10). The first anomaly, including samples S49, S51 and S53, located between Marambaia Barrier Island and Guaíba Island (Fig. 1), presents markedly higher ${ }^{206} \mathrm{~Pb} /{ }^{207} \mathrm{~Pb}$ ratios for leaching than for complete dissolution (Fig. 10). On the other hand, the second group, composed of samples S21, S25, S27 and S47, located around Jaguanum Island and near the Ponta da Marambaia (Fig. 1), displays isotopic ratios ${ }^{206} \mathrm{~Pb} / 207 \mathrm{~Pb}$ expressively lower for leaching than for the total dissolution method (Fig. 10).

Anomaly 1 is inserted in an area with samples, including $\mathrm{S} 51$, that exhibit ${ }^{206} \mathrm{~Pb} /{ }^{207} \mathrm{~Pb}$ ratios that are higher for leaching than for total dissolution (Fig. 10), indicating an external source of $\mathrm{Pb}$ to the sediments. As mentioned above, sample S51 presented ${ }^{206} \mathrm{~Pb} /{ }^{207} \mathrm{~Pb}$ ratios, determined by leaching, that are similar to those from samples SP11 and SP12 from Saco do Engenho, a highly anthropized zone of Sepetiba Bay analyzed by Cunha et al. (2009; Fig. 1). These results suggest that sediments found around station S51 came from an area close to Saco do Engenho (Fig. 1).

Anomaly 1 is located in the area considered adequate for the disposal of sediments dredged from the navigational channel giving access to Sepetiba port according to Companhia Docas of Rio de Janeiro (see Area 2 in Fig. 1). However, after the Environmental Impact Report (RIMA) evaluation (Ecologus, 2014), this area was not chosen to dump the dredged material. 


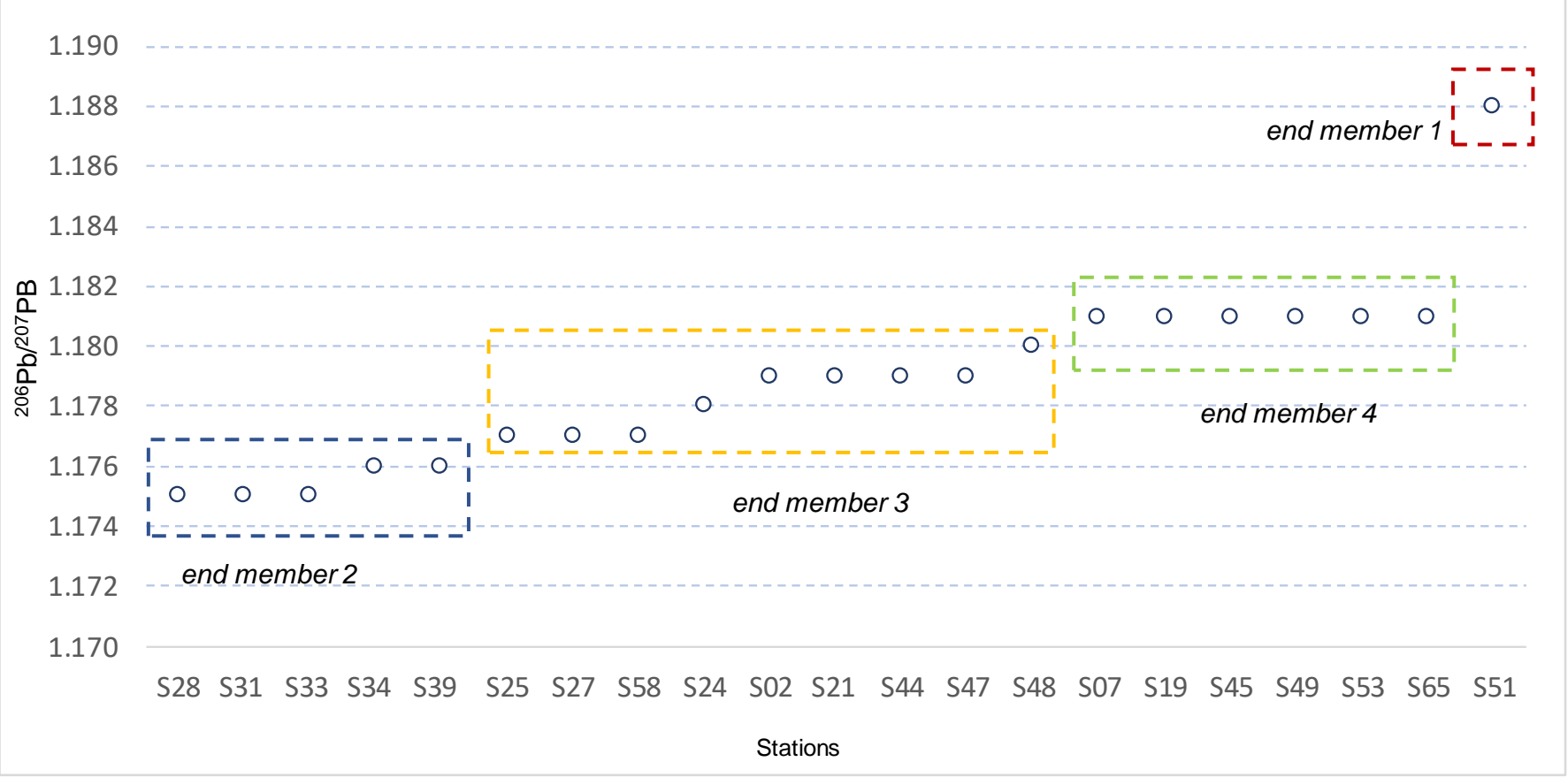

Fig. 6. Identification of the isotopic signatures of $\mathrm{Pb}$ obtained by the leaching technique, through the increasing order of ${ }^{206} \mathrm{~Pb} /{ }^{207} \mathrm{~Pb}$ values of the analyzed samples in this work.

It is also interesting to note that in a more central region of Sepetiba Bay, near Ponta da Pombeba, there is an area that was used to dump dredged sediment from the main navigational channel (indicated in Fig. 1 by \#24) in addition to another area, used by the Companhia Docas of Rio of Janeiro (Area 1 of Fig. 1). These dredged sediments, originated from areas under heavy industrial influence (especially from the region of Saco do Engenho, an outlet for the industrial residues of the decommissioned Mercantil Ingá mining industry tailings; Fig. 1B) may have been redistributed through the western sector of Sepetiba Bay, by the local circulation (Fig. 11).

Anomaly 2 also suggests the presence of sediments from an external source, probably anthropogenic. This anomaly is represented by samples S21, S25, S27 and S47 and defines a $\mathrm{Pb}$ isotopic signature $\left({ }^{206 \mathrm{~Pb}} /{ }^{207} \mathrm{~Pb}\right)$ higher than 1.2 . This more radiogenic signature is clearly identified in the diagram of Fig. 10, but it is not easily discernible in Figs. 5, 7 and 13. A similar signature was reported by Rocha (2011) and Aily (2001) and, according to these authors, its origin may be related to gasoline and domestic pollutants.

\section{$3.3 \mathrm{~V}$ alues of ${ }^{206} \mathrm{~Pb} /{ }^{207} \mathrm{~Pb}$ versus $\mathrm{Pb}$ concentrations}

The correlation between ${ }^{206} \mathrm{~Pb} /{ }^{207} \mathrm{~Pb}$ ratios determined by the total dissolution technique, and by the total $\mathrm{Pb}$ concentration shows that, in general, increasing concentrations of $\mathrm{Pb}$ are associated with low isotope ratios (quadrant 4 in Fig. 12). Eleven of the nineteen analyzed samples were positioned in quadrant 4 , and presented ${ }^{206 \mathrm{~Pb}} /{ }^{207} \mathrm{~Pb}$ ratios between 1.163 and 1.196 , and lead concentrations between 21 and $29 \mu \mathrm{g} \mathrm{g}^{-1}$ (Fig. 12).
Sun et al. (2011) also observed low values of ${ }^{206 \mathrm{~Pb} / 207 \mathrm{~Pb}}$ ratios, obtained by the total dissolution method, associated with the most enriched samples in total $\mathrm{Pb}$ in the Yangtze River (China) and considered this tendency characteristic of areas under anthropic influence. Thus, the relationship between the highest concentrations of total $\mathrm{Pb}$ and the lowest ${ }^{206 \mathrm{~Pb} / 207} \mathrm{~Pb}$ ratios, obtained by the total dissolution method, suggests that the study area is under strong anthropogenic influence.

The correlation between ${ }^{206 \mathrm{~Pb}} /{ }^{207} \mathrm{~Pb}$ ratios obtained by the leaching method and the partial concentrations of $\mathrm{Pb}$ (leached) reveals that samples with relatively high partial $\mathrm{Pb}$ content are included in quadrant 4 (Fig. 13). On the other hand, the small range of ${ }^{206 \mathrm{~Pb} /} /{ }^{207} \mathrm{~Pb}$ ratios, between 1.175 and 1.188, and the location of all samples, except S51, in quadrants 3 and 4 (Fig. 13) suggest that there is a homogenizing effect of the isotopic signature of the sediments in the study area, an idea reinforced by the results obtained through the leaching technique for both, the ${ }^{206} \mathrm{~Pb} /{ }^{207} \mathrm{~Pb}$ ratios and the partial concentrations of $\mathrm{Pb}$.

Results presented in Fig. 13 also reveal that there is a significant number of samples (belonging to quadrant 3) with relatively low partial $\mathrm{Pb}$ concentrations and ${ }^{206} \mathrm{~Pb} /{ }^{207} \mathrm{~Pb}$ ratios (leaching). Similar results were obtained by Santos et al. (2012) in sediments of an anthropized area of the Guamá River (Belém, N Brazil), also using the leaching method. Santos et al. (2012) related their results to varying $\mathrm{pH}$ and the presence of organic matter in the sediments. In general, low $\mathrm{pH}$ values (4 to 6 ) are found in sediments enriched in organic matter. 

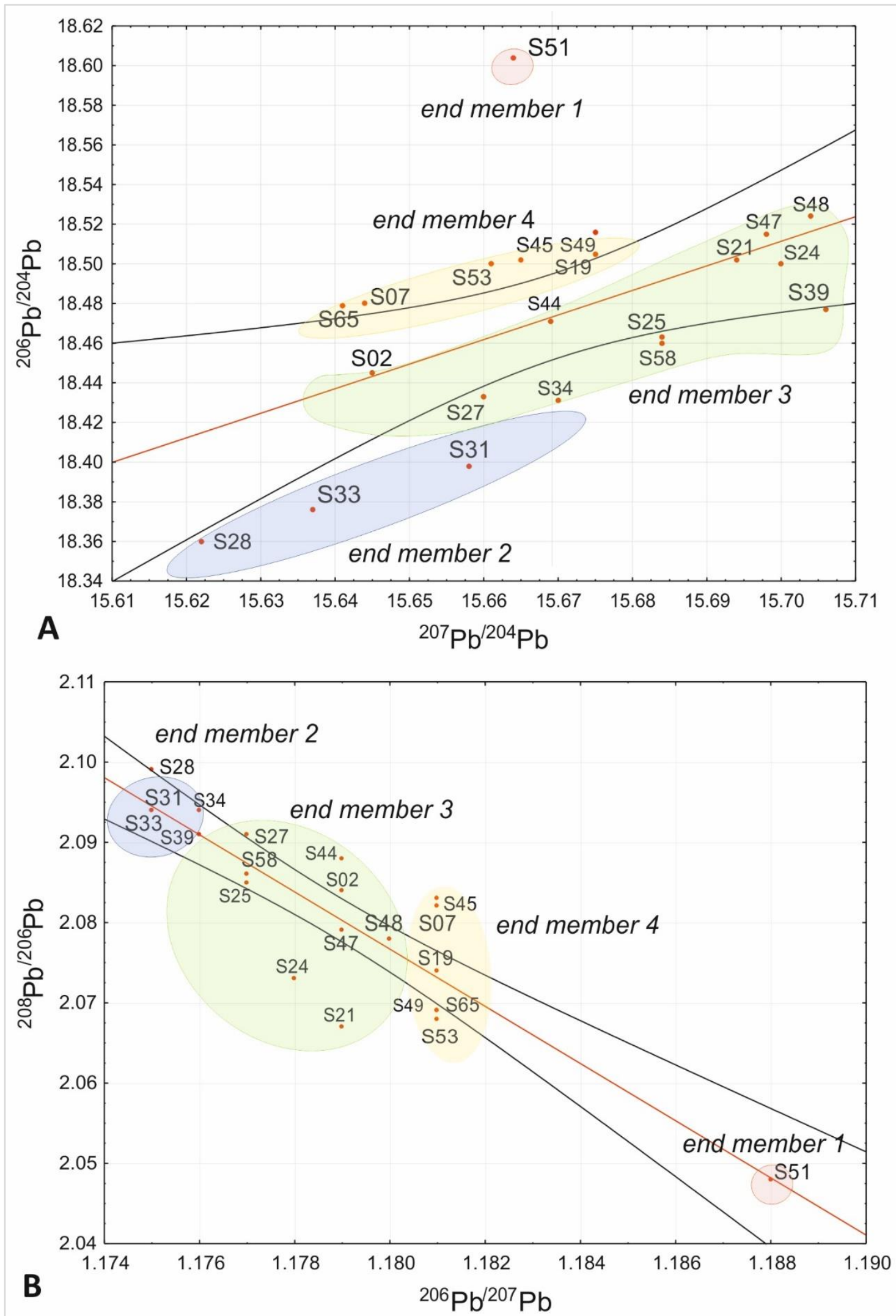

Fig. 7. Isotopic ratios obtained through the leaching method and correlations between ${ }^{206} \mathrm{~Pb} /{ }^{204} \mathrm{~Pb}$ versus ${ }^{207} \mathrm{~Pb} /{ }^{204} \mathrm{~Pb}(\mathrm{~A})$ and ${ }^{208} \mathrm{~Pb} /{ }^{206} \mathrm{~Pb}$ versus ${ }^{207} \mathrm{~Pb} /{ }^{206} \mathrm{~Pb}(\mathrm{~B})$, for the stations highlighted in Fig. 1 (western sector of Sepetiba Bay). End members identified by circles of different colors (red - end member 1; blue - end member 2; green - end member 3; yellow - end member 4). 


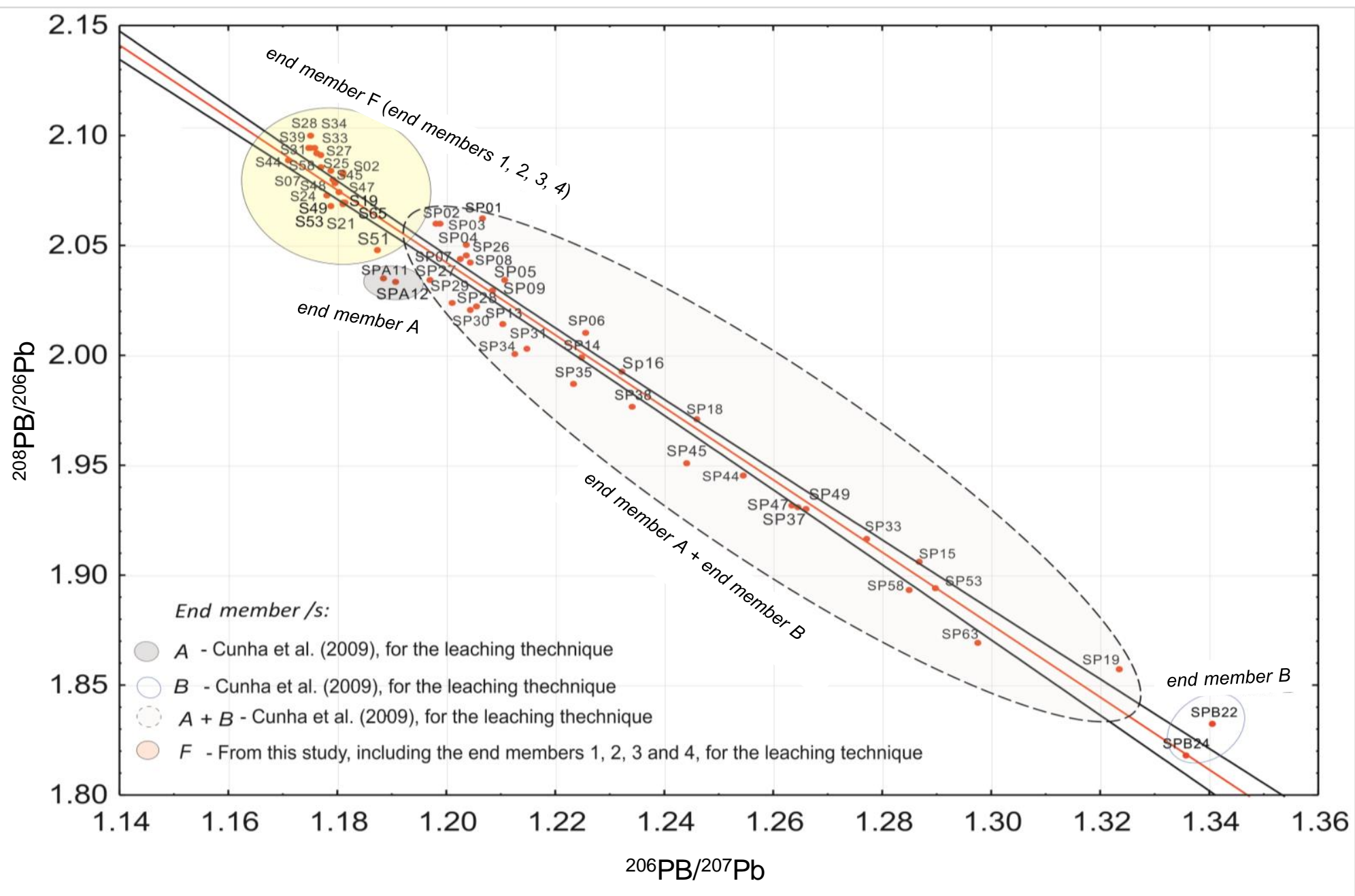

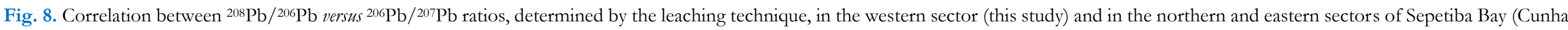
et al., 2009). 
${ }^{206} \mathrm{~PB} / 207 \mathrm{~Pb}$

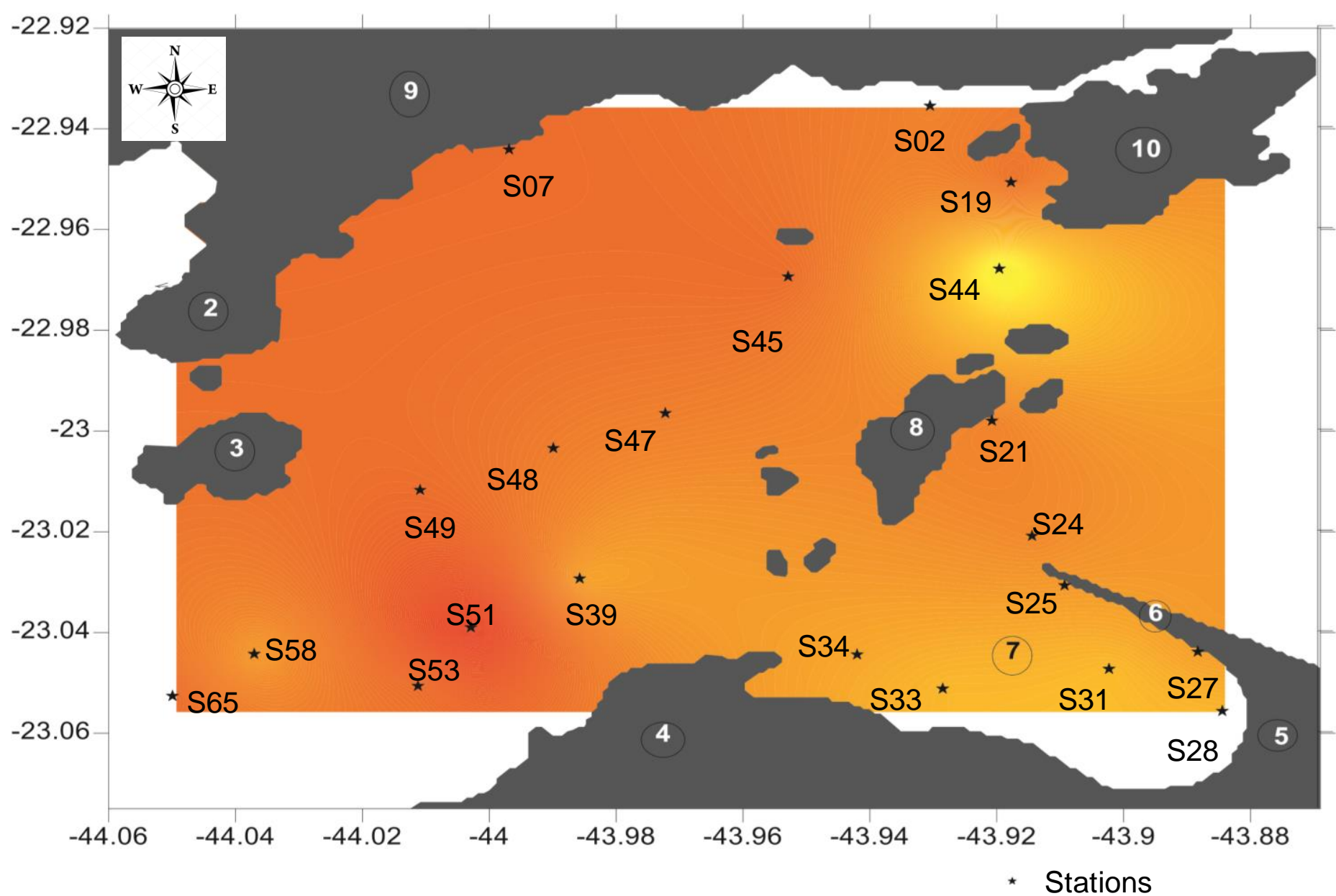

Leaching

Fig. 9. Spatial distribution of the isotopic signatures of $\mathrm{Pb}\left({ }^{206 \mathrm{~Pb}} / 207 \mathrm{~Pb}\right)$ obtained by the leaching method. 2- Mangaratiba; 3- Guaíba Island (Port terminal); 4- Ponta da Marambaia; 5- Marambaia Barrier Island; 6- Ponta da Pombeba; 7- Marambaia Bay; 8- Jaguanum Island; 9- Saí River; 10- Itacuruçá Island. 


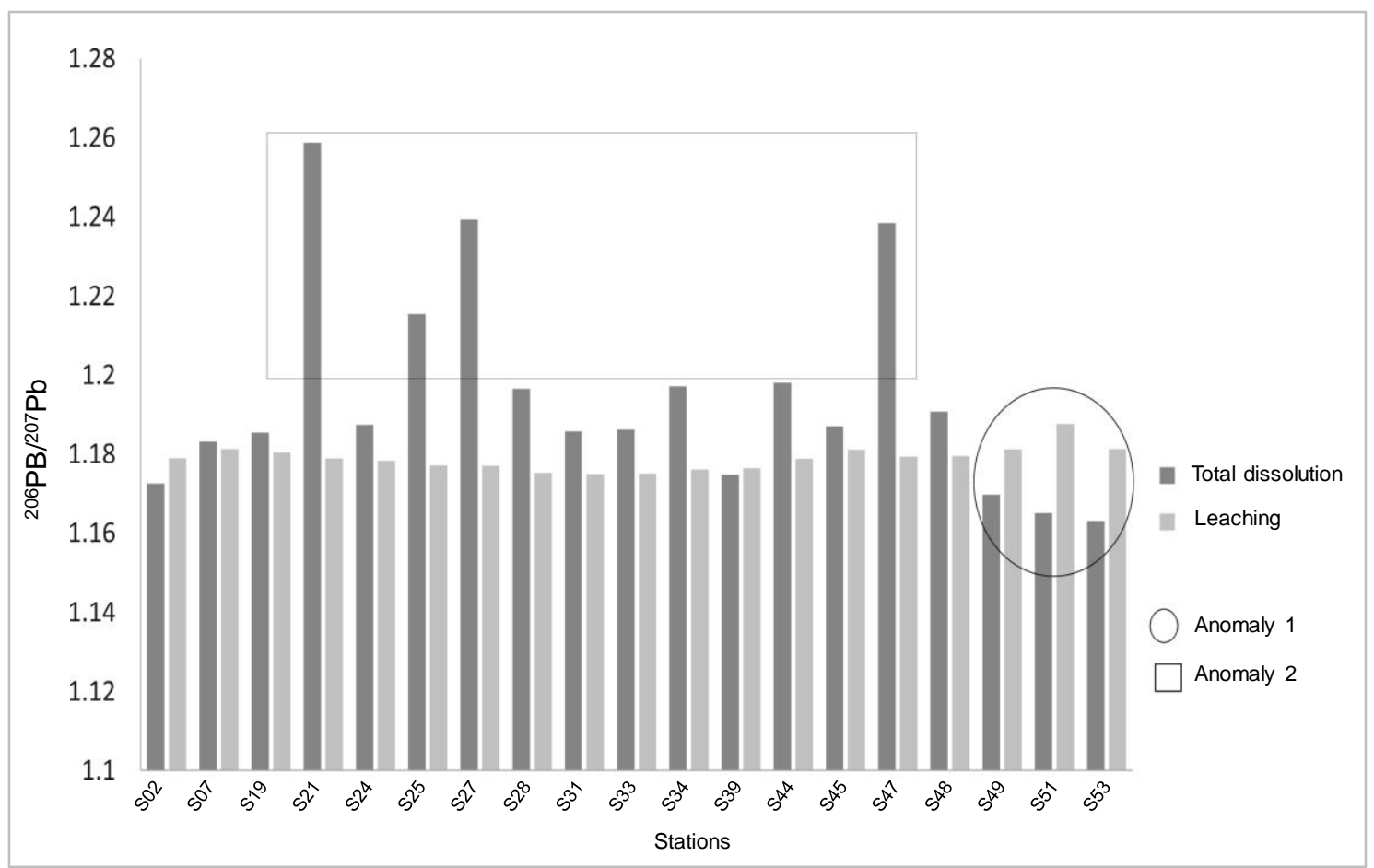

Fig. 10. Comparison between the ${ }^{206} \mathrm{~Pb} /{ }^{207} \mathrm{~Pb}$ ratios obtained by total dissolution and leaching techniques for the stations highlighted in Fig. 1. Stations inserted in the circle are related to Anomaly 1, in which ${ }^{206} \mathrm{~Pb} /{ }^{207} \mathrm{~Pb}$ ratios obtained by the leaching technique were markedly higher than those obtained by the total dissolution technique. Stations included in the rectangle are related to Anomaly 2 and have ${ }^{206} \mathrm{~Pb} /{ }^{207} \mathrm{~Pb}$ ratios obtained by total dissolution markedly higher than those determined by the leaching technique.

Under such conditions, lead previously complexed to organic matter is released for the water column, resulting in a decrease of this element concentration in the sediment compartment (Santos et al., 2012). However, in such conditions, the anthropogenic signature of lead isotopes is maintained. It is therefore supposed that processes similar to those observed by Santos et al. (2012) in the Guamá River (Belém, N Brazil), may also occur in the study area.

\subsection{Comparison of $\mathrm{Pb}$ signatures obtained in different Brazilian regions}

${ }^{206} \mathrm{~Pb} /{ }^{207} \mathrm{~Pb}$ ratios from the western sector of Sepetiba Bay (data of this work; Fig. 1), a region with a free communication with the continental shelf, were compared with data obtained in previous works (Cunha et al., 2009; Rocha, 2011), in samples collected in the northern and central-eastern sectors of Sepetiba Bay, including areas near Sepetiba Port, the decommissioned Mercantil Ingá mining industry, at rivers and streams mouths and close to the northern shore of Marambaia Barrier Island (Table 4). In general, the western sector of Sepetiba Bay presented higher

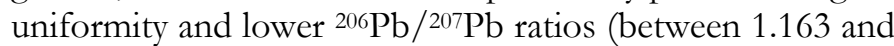
1.259 , mean $1.194 \pm 0.027$, for the total dissolution technique, and between 1.175 and 1.188 , mean $1.179 \pm 0.003$, for the leaching technique) than the eastern sector, where values ranged between 1.188 and 1.341 (mean $1.237 \pm 0.042$ ), for the leaching technique (Cunha et al., 2009) and between 1.174 and 1.303 (mean $1.211 \pm 0.037$ ), for the total dissolution technique (Rocha, 2011; Table 4).

The comparison of ${ }^{206 \mathrm{~Pb}} /{ }^{207} \mathrm{~Pb}$ ratios obtained in this study through total dissolution (1.163 to 1.259) and leaching (1.175 to 1.188$)$ techniques with values obtained in other studies carried out in several Brazilian regions (Bollhöfer and Rosman, 2000; Aily, 2001; Moura et al., 2004; Gioia et al., 2006; Santos et al., 2012) evidences their similarity with signatures associated with gasoline and with regions under heavy industrial and urban pressure (Fig. 14). On the other hand, the values obtained in this study are higher than those obtained by Geraldes et al. (2006) in Guanabara Bay, that is influenced by several anthropogenic activities (Potratz et al., 2019), and where ${ }^{206} \mathrm{~Pb} /{ }^{207} \mathrm{~Pb}$ ratios ranged between 1.092 and 1.151 (Fig. 14). The higher metal contents in sediments from Sepetiba bay might be related to the Mercantil Ingá melt of $\mathrm{Pb}$ and $\mathrm{Zn}$ ores during several decades.

In addition, the values obtained through total dissolution were within the range of ratios reported by Marques Jr. et al. (2006), that applied the same technique to samples of a $50 \mathrm{~cm}$-long sediment core collected in the area of Coroa Grande mangrove (Sepetiba Bay). These authors obtained ${ }^{206} \mathrm{~Pb} /{ }^{207} \mathrm{~Pb}$ ratios ranging from 1.161 to 1.180 in pre-industrial sediments (between 40 and $50 \mathrm{~cm}$ ) and from 1.183 to 1.198 , in post-industrial sediment layers (between $40 \mathrm{~cm}$ and the core top), coinciding with end member 1 (1.163 to 1.173 ) and end member 2 (1.183 to 1.198$)$, respectively. 
Tab. 4. Comparison between ${ }^{206} \mathrm{~Pb} /{ }^{207} \mathrm{~Pb}$ ratios obtained in this work and in the northern and central-eastern sectors of Sepetiba Bay (Cunha et al., 2009; Rocha, 2011). The minimum and maximum values and the mean and standard deviation (SD) values are also presented.

${ }^{206} \mathrm{~Pb}^{/ 207} \mathrm{~Pb}$ (Sepetiba Bay)

\begin{tabular}{|c|c|c|c|c|c|c|}
\hline \multirow{3}{*}{ Stations } & \multirow{2}{*}{\multicolumn{2}{|c|}{$\begin{array}{c}\text { West Sector } \\
\text { Present study }\end{array}$}} & \multicolumn{4}{|c|}{ North and Central East Sectors } \\
\hline & & & \multicolumn{2}{|c|}{ Cunha et al. (2009) } & \multicolumn{2}{|c|}{ Rocha (2011) } \\
\hline & $\begin{array}{c}\text { Total } \\
\text { Dissolution }\end{array}$ & Leaching & Stations & Leaching & Stations & $\begin{array}{c}\text { Total } \\
\text { Dissolution }\end{array}$ \\
\hline $\mathrm{S} 02$ & 1.173 & 1.179 & SP01 & 1.207 & SP10 & 1.222 \\
\hline S07 & 1.183 & 1.181 & SP02 & 1.199 & SP20 & 1.207 \\
\hline S19 & 1.185 & 1.181 & SP03 & 1.198 & SP21 & 1.259 \\
\hline S21 & 1.259 & 1.179 & SP04 & 1.204 & SP23 & 1.290 \\
\hline S24 & 1.187 & 1.178 & SP05 & 1.211 & SP41 & 1.185 \\
\hline S25 & 1.215 & 1.177 & SP06 & 1.226 & SP42 & 1.186 \\
\hline S27 & 1.239 & 1.177 & SP07 & 1.203 & SP54 & 1.181 \\
\hline S28 & 1.197 & 1.175 & SP08 & 1.205 & SP57 & 1.190 \\
\hline S31 & 1.186 & 1.175 & SP09 & 1.209 & SP59 & 1.261 \\
\hline S33 & 1.186 & 1.175 & SP11 & 1.188 & SP61 & 1.187 \\
\hline S34 & 1.197 & 1.176 & SP12 & 1.191 & SP65 & 1.223 \\
\hline S39 & 1.175 & 1.176 & SP13 & 1.211 & SP67 & 1.189 \\
\hline S44 & 1.198 & 1.171 & SP14 & 1.225 & SP72 & 1.187 \\
\hline S45 & 1.187 & 1.181 & SP15 & 1.287 & SP75 & 1.183 \\
\hline S47 & 1.238 & 1.179 & SP16 & 1.233 & SP77 & 1.190 \\
\hline S48 & 1.191 & 1.180 & SP18 & 1.246 & SP83 & 1.174 \\
\hline S49 & 1.170 & 1.181 & SP19 & 1.324 & SP86 & 1.186 \\
\hline S51 & 1.165 & 1.188 & SP22 & 1.341 & SP87 & 1.210 \\
\hline S53 & 1.163 & 1.181 & SP24 & 1.336 & SP89 & 1.214 \\
\hline S58 & ---- & 1.177 & SP33 & 1.277 & SP90 & 1.303 \\
\hline S65 & ---- & 1.181 & SP37 & 1.266 & SP91 & 1.204 \\
\hline ---- & ---- & ---- & SP26 & 1.204 & ---- & ---- \\
\hline ---- & ---- & ---- & SP27 & 1.197 & ---- & ---- \\
\hline ---- & ---- & ---- & SP28 & 1.206 & ---- & ---- \\
\hline ---- & ---- & ---- & SP29 & 1.201 & ---- & ---- \\
\hline ---- & ---- & ---- & SP30 & 1.205 & ---- & ---- \\
\hline ---- & ---- & ---- & SP31 & 1.215 & ---- & ---- \\
\hline ---- & ---- & ---- & SP34 & 1.213 & ---- & ---- \\
\hline ---- & ---- & ---- & SP35 & 1.223 & ---- & ---- \\
\hline ---- & ---- & ---- & SP38 & 1.234 & ---- & ---- \\
\hline ---- & ---- & ---- & SP44 & 1.255 & ---- & ---- \\
\hline ---- & ---- & ---- & SP45 & 1.244 & ---- & ---- \\
\hline ---- & ---- & ---- & SP47 & 1.265 & ---- & ---- \\
\hline ---- & ---- & ---- & SP49 & 1.264 & ---- & ---- \\
\hline ---- & ---- & ---- & SP53 & 1.290 & ---- & ---- \\
\hline ---- & ---- & ---- & SP58 & 1.285 & ---- & ---- \\
\hline ---- & ---- & ---- & SP63 & 1.298 & ---- & ---- \\
\hline Minimum & 1.163 & 1.175 & Minimum & 1.188 & Minimum & 1.17 \\
\hline Maximum & 1.259 & 1.188 & Maximum & 1.341 & Maximum & 1.303 \\
\hline Mean $\pm S D$ & $1.194 \pm 0.027$ & $1.179 \pm 0.003$ & Mean \pm SD & $1.237 \pm 0.043$ & Mean \pm SD & $1.211 \pm 0.037$ \\
\hline
\end{tabular}



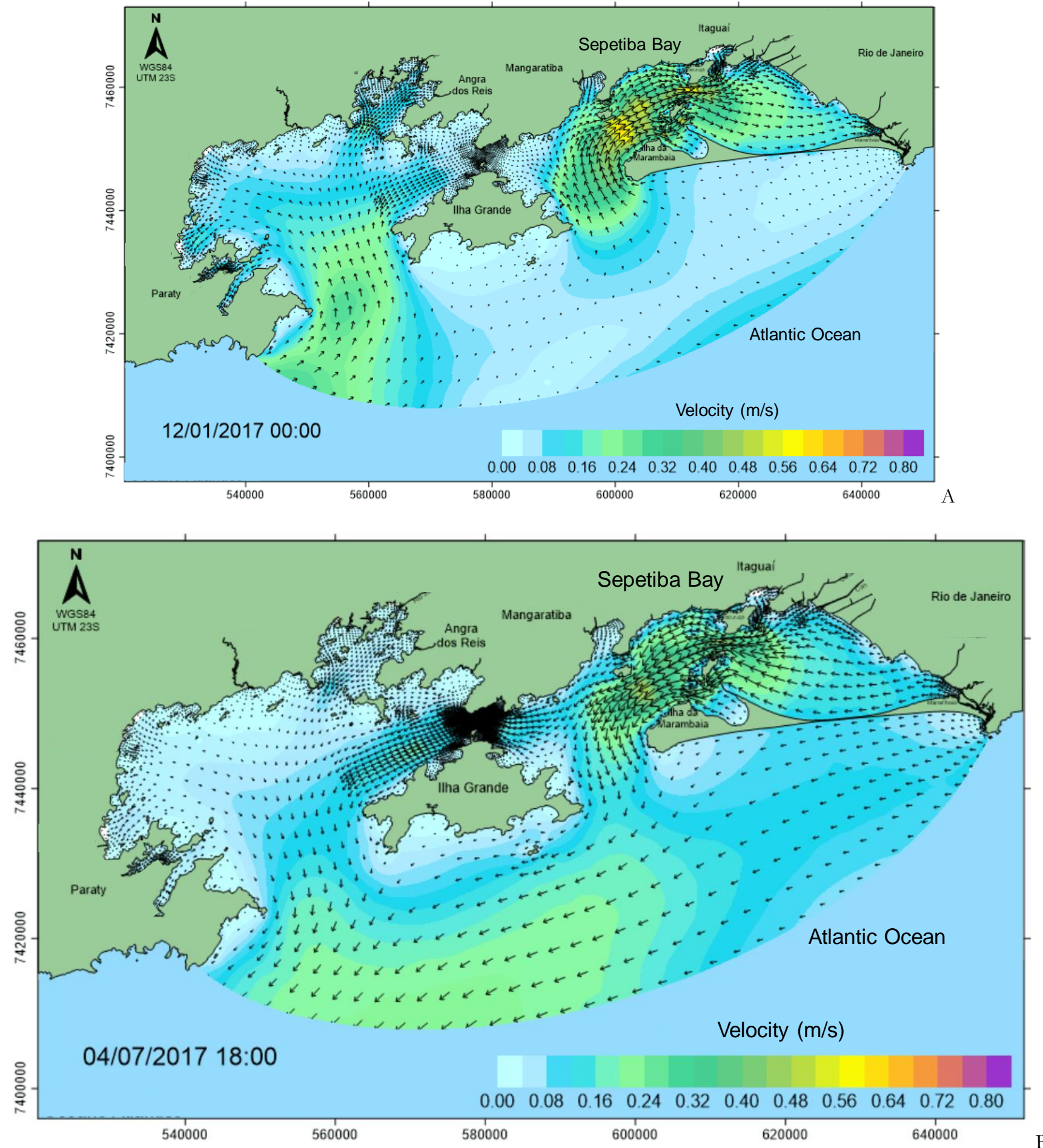

Fig. 11. Direction and intensity of (A) flood and (B) ebb tidal currents in the Ilha Grande and Sepetiba bays (adapted from Favaro dos Santos et al., 2019).

Furthermore, the isotopic signature of ${ }^{206} \mathrm{~Pb} /{ }^{207} \mathrm{~Pb}$ found in the western sector of Sepetiba Bay was similar to that of polluted sediments of Brazilian continental areas (Fig. 14) such as Paranoá Lake (Brasilia, DF; Gioia et al., 2006) and the metropolitan area of Belém (N Brazil; Santos et al., 2012; Moura et al., 2004) confirming the anthropic influence and dispersion of pollutants in Sepetiba Bay by the local hydrodynamics.

Even though the western sector of Sepetiba Bay presents relatively low industrial and urban concentration, and receives reduced volumes of continental effluent discharge, restricted to the Saí River (area \#9 of Fig. 1), the ${ }^{206 \mathrm{~Pb} /}{ }^{207} \mathrm{~Pb}$ ratios are similar to those of Madeira Island and Saco do Engenho region (Fig. 1), which is an urban, port and steel industry center. This similarity supports the hypothesis that sediments were redistributed by the local hydrodynamics within Sepetiba Bay (Favaro dos Santos et al., 2019), being removed from contaminated areas located in the eastern, central-north zones of this bay or from dump sites of dredged sediments. 


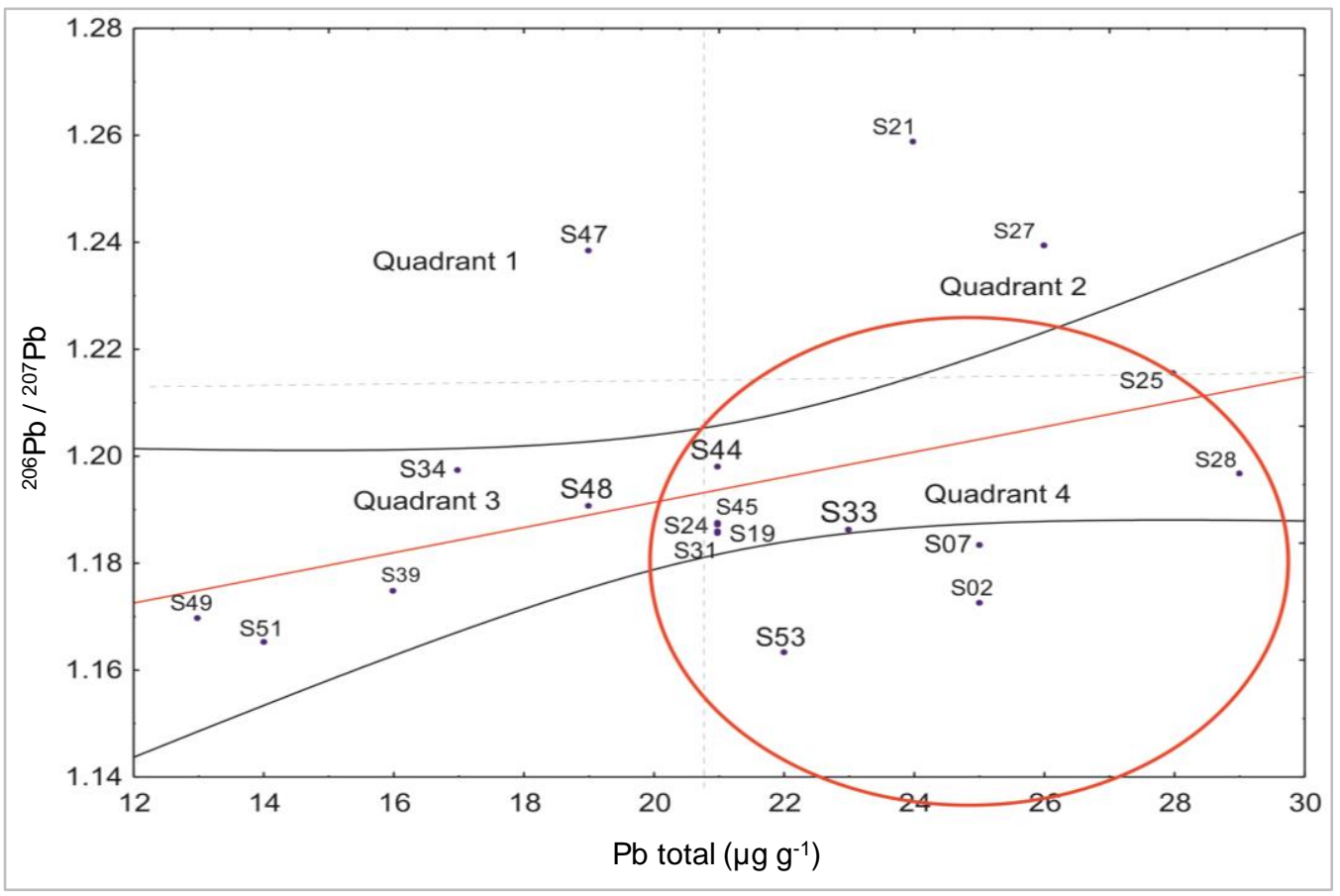

Fig. 12. Correlation between ${ }^{206} \mathrm{~Pb} /{ }^{207} \mathrm{~Pb}$ ratios obtained by total dissolution technique and total $\mathrm{Pb}$ concentrations for the stations highlighted in Fig. 1. Samples that presented relatively high $\mathrm{Pb}$ concentrations and low ${ }^{206} \mathrm{~Pb} /{ }^{207} \mathrm{~Pb}$ ratios are inserted in the red circle.

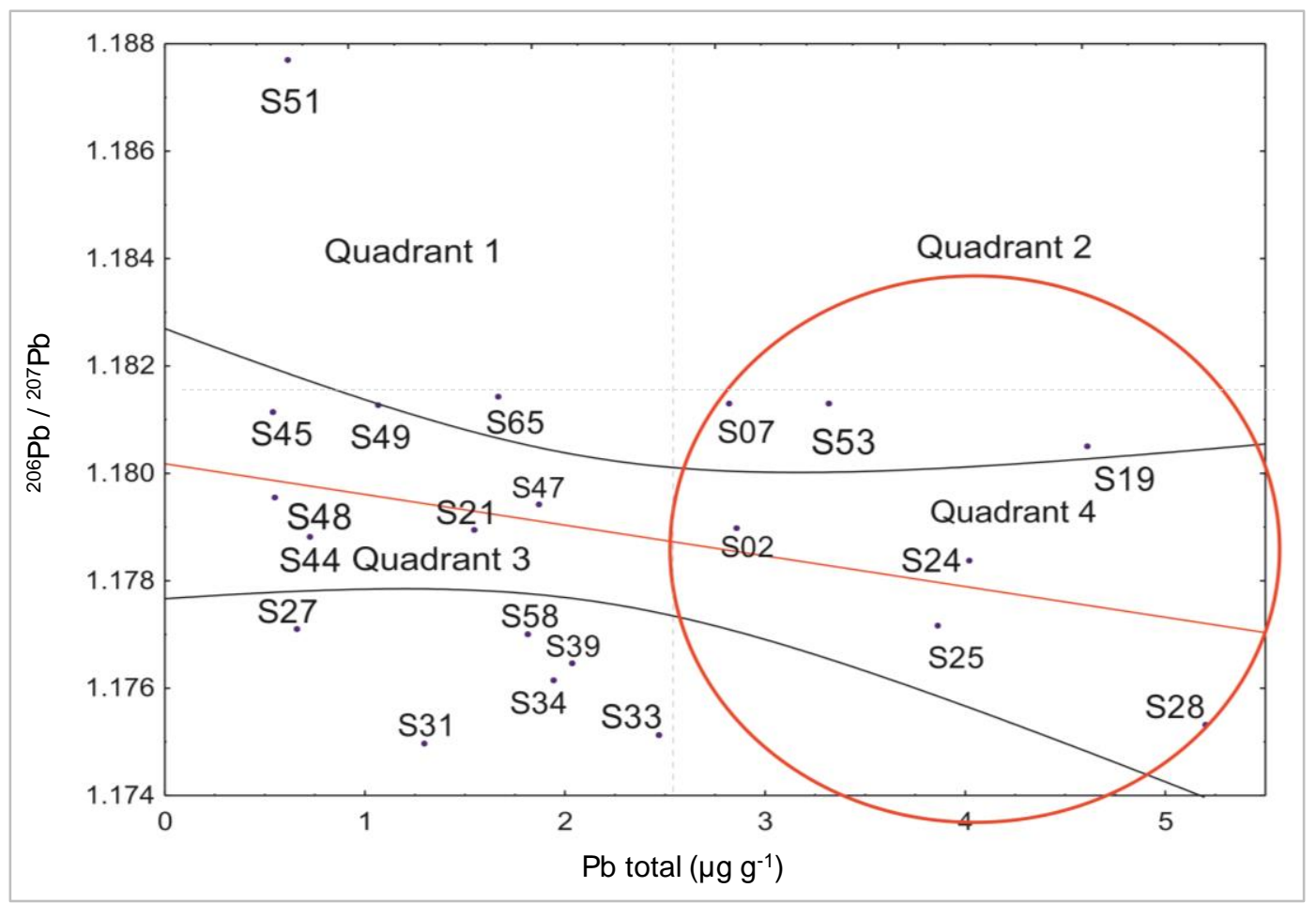

Fig. 13. Correlation between the ${ }^{206} \mathrm{~Pb} /{ }^{207} \mathrm{~Pb}$ ratios (leaching technique) and the partial $\mathrm{Pb}$ concentration $\left(\mu \mathrm{g} \mathrm{g}^{-1}\right)$ at the stations highlighted in Fig. 1. Samples that presented high values of partial concentrations of $\mathrm{Pb}$ are inserted in the red circle. 


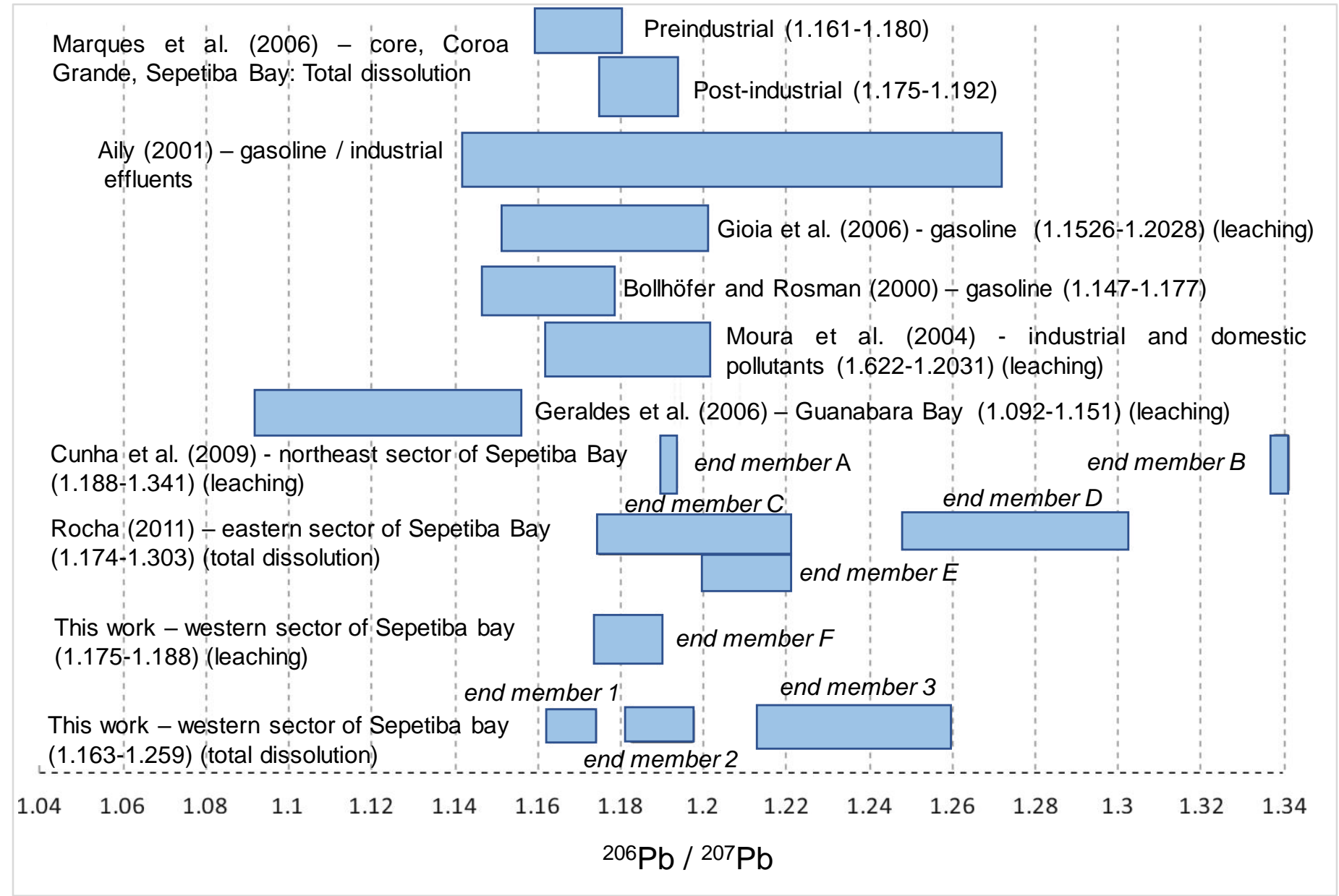

Fig. 14. Comparison between the ${ }^{206} \mathrm{~Pb} /{ }^{207} \mathrm{~Pb}$ isotopic signatures found in this study and other studies. Data are related to both total dissolution and leaching techniques.

Thus, we can consider that the economic activities developed in Sepetiba Bay, together with the dredging activities and the atmospheric $\mathrm{Pb}$ deposition contribute to the isotopic signature of the bottom sediments. This signature seems to be also influenced by the tidal currents' activity, sedimentary dynamics (remobilization and transport of suspended materials) and biogeochemical processes.

\section{Conclusion}

Regardless the total and partial concentrations of $\mathrm{Pb}$, and their distribution, the results obtained in this work allowed to deduce that the sediments of the western zone of Sepetiba Bay, contain a clear anthropogenic isotopic signature.

In the study area the ${ }^{206} \mathrm{~Pb} / 207 \mathrm{~Pb}$ ratios are more homogeneously distributed than in the neighboring areas, presenting values between 1.163 and 1.259 for the total dissolution technique and between 1.175 and 1.188 for the leaching technique. Samples with large differences between ${ }^{206 \mathrm{~Pb}} / 207 \mathrm{~Pb}$ ratios obtained by leaching and by complete dissolution were considered anomalies. The two identified anomalies are related to the presence of an external sediment source, probably anthropogenic. Anomaly 1 traces the occurrence of sediments sourced by the decommissioned Mercantil Ingá mining industry tailings area, as well as gasoline and domestic and industrial effluents that reach Sepetiba Bay.

Sediments analyzed in this study have an isotopic signature similar to that found in the north-northeast area of Sepetiba Bay, a region under strong port, industrial and urban pressure, but exhibit more uniform and less radiogenic isotopic signatures. These results suggest that the tidal current system cause sediment remobilization, transport and dispersion from dredging disposal areas to the western region of Sepetiba Bay.

The analysis of the $\mathrm{Pb}$ isotopic signature through the integrated use of total dissolution and leaching techniques allowed to trace the presence of anthropogenic sediments in the western boundary of Sepetiba Bay and to identify the dispersion of contaminated sediments from inner bay areas to the outermost region, both by the effect of dredging operations and natural processes. 


\section{Acknowledgments}

The authors would like to thank the Coordenação de Aperfeiçoamento de Pessoal de Nivel Superior (CAPES) for financing the project Estuarine and continental shelf fine sediments: Formation and dynamics of mud deposits (Call Marine Science 2010) and for the master's fellowship granted to the first author; the Fundação de Amparo à Pesquisa do Estado do Rio de Janeiro (FAPERJ) for financing the project Interaction between Sepetiba and Ilha Grande Bays: circulation and sedimentation patterns and the anthropic influence (Call Pensa Rio 2009). Special thanks to Margareth S. Navarro and Jacinta Enzweiler, from Analytical Geochemistry Laboratory (UNICAMP), to the technicians of Sample Preparation Geological Laboratory (FGEL, UERJ) and to the colleagues from PPG-OCN, who took part in the sampling campaigns. The first author would like to thank the Conselho Nacional de Desenvolvimento Científico e Tecnológico of Brazil (CNPq) by the research grant (reference number: 301588/2016-3) and the project process \# 443662/2018-5). Virginia Martins and Mauro Geraldes would like to thank the $\mathrm{CnPq}$ for the research grants (process \# 301588/2016-3 and process \# 301470/2016-2, respectively).

\section{References}

Aily, C., 2001. Caracterização Isotópica de Pb na atmosfera: um exemplo da cidade de São Paulo. 2001. MsD Thesis, Universidade Federal de São Paulo, São Paulo, 76 p.

Bollhöfer, A., Rosman, K.J.R., 2000. Isotopic source signatures for atmospheric lead: the Southern Hemisphere. Geochimica et Cosmochimica Acta 64 (19), 3251-3262. https://doi.org/10.1016/S0016-7037(00)00436-1

Costa, L.C., Ferreira, A.P., Neves, E.B., 2011. Aplicação do Sistema de Projeção de Poluição Industrial (Modelo IPPS) na bacia hidrográfica da baía de Sepetiba (Rio de Janeiro, Brasil): estudo de caso. Caderno Saúde Coletiva 19 (1), 66-73.

Cunha, B.C.A., Rocha, D., Geraldes, M.C., Pereira, S.D., Almeida, A.C., 2009. Pb isotopic signatures in sediments of a subtropical coastal lagoon: anthropogenic sources for metal contamination in the Sepetiba Bay (SE-Brazil). Journal of Coastal Research 56, 797-801.

Díaz Morales, S.J., Guerra, J.V., Nunes, M.A.S, Souza, A.M., Geraldes, M.C., 2019. Evaluation of the environmental state of the western sector of Sepetiba Bay (SE Brazil): trace metal contamination. Journal of Sedimentary Environments, 4 (2): 174-188. https://doi.org/10.12957/jse.2019.43764

Ecologus, Engenharia Consultiva, 2016. Obras de expansão do terminal de containers, Sepetiba. Rima, Relatório de Impacto Ambiental. TECON, Concremat Ambiental. Instituto Estadual do Ambiente (Rio de Janeiro), 51 p. http://www.inea.rj.gov.br, accessed on 23.08.2019

Ecologus, Engenharia Consultiva, 2014. Terminal de Granéis Sólidos - TECAR 70 Mtpa. Ecologus, Relatório de Impacto Ambiental, CSN - Companhia Siderurgica Nacional, RIMA, Relatório de Impacto Ambiental, 124 p. http:/ /www.inea.ri.gov.br, accessed on 23.08.2019

Ecologus, Engenharia Consultiva, 2008. Serviços de Dragagem no acesso aquaviário ao Complexo Industrial do Porto organizado de Itaguaí. Rio de Janeiro, Ecologus, RIMA, Relatório de Impacto Ambiental, 113 p. http://www.inea.rj.gov.br, accessed on 23.08.2019
Favaro dos Santos, A.L., Ponte, L., Peixoto, R.S., Rosman, P.A., Rosman, P.C.C., 2018. Projeto Baías Do Brasil: Baías de Ilha Grande e Sepetiba - Rj. Sistema base de hidrodinâmica ambiental. COPE, Engenheira Costeira e Oceanográfica, Rio de Janeiro. http://baiasdobrasil.ivig.coppe.ufrj.br/assets/relatorios/rel_il hagrande_sepetiba.html\#4.3 (acessed on 11/08/2019.

FEEMA, Fundação Estadual do Rio de Janeiro, 2006. Baía de Sepetiba - Rios da baixada da Baía de Sepetiba - Diagnóstico de qualidade de água e sedimento. Relatório. Rio de Janeiro.

Ferreira, A.P., Moreira, M.F.R., 2015. Metals Pollution Status in Surface Sediments along the Sepetiba Bay Watershed, Brazil. Journal of Coastal Zone Management 18, 1-5. https://doi.org/10.4172/2473-3350.1000404

Ferreira, A.P., 2011. Assessment of heavy metals in Egretta thula. Case study: Coroa Grande mangrove, Sepetiba Bay, Rio de Janeiro, Brazil. Brazilian Journal of Biology 71, 77-82. http:/ /dx.doi.org/10.1590/S1519-69842011000100012

Ferreira, A.P., Horta, M.A.P., 2010. Trace element residues in water, sediments, and organs of Savacu (Nycticorax nycticorax) from Sepetiba Bay, Rio de Janeiro, Brazil. Revista Ambiente \& Água 5, 1-12.

Ferreira, A.P., 2009. Avaliação das concentrações de metais pesados no sedimento, água e em Leucopternis lacernulata (gavião-pomba). Estudo de caso: Baía de Sepetiba, Rio de Janeiro. Gaia Scientia 3 (2), 23 - 31

FIRJAN, Federação das Indústrias do Estado do Rio de Janeiro, 2012. Decisão Rio - Investimentos 2012 - 2014. Sistema FIRJAN.

Geraldes, M.C., Paula, A.H., Godoy, J.M., Valeriano, C.M., 2006. $\mathrm{Pb}$ isotope signatures of sediments from Guanabara Bay, SE Brazil: evidence for multiple anthropogenic sources. Journal of Geochemical Exploration 88 (1-3), 384-388. https://doi.org/10.1016/j.gexplo.2005.08.081

Gioia, S.M.C.L., Pimentel, M.M., Tessler, M., Dantas, E.L., Campos, J.E.G., Guimarães, E.M., Maruoka, M.T.S., Nascimento, E.L.C., 2006. Sources of anthropogenic lead in sediments from an artificial lake in Brasilia, central Brazil. The Science of the Total Environment 356 (1), 125-142. https://doi.org/10.1016/j.scitotenv.2005.02.041

Hansmann, W., Köppel, V., 2000. Lead-isotopes as tracers of pollutants in soils. Chemical Geology 171, 123-144.

Miranda Filho, A. L., Mota, A. K. M.; Cruz, C. C., Matias, C.A.R, Ferreira, A.P., 2011. Cromo hexavalente em peixes oriundos da Baía de Sepetiba no Rio de Janeiro, Brasil: uma avaliação de risco à saúde humana. An Interdisciplinary Journal of Applied Science 6, 200-209. http://dx.doi.org/10.4136/ambi-agua.568

Molisani, M.M., Marins, R.V., Machado, W., Paraquetti, H.H.M., Bidone, E.D., Lacerda, L.D., 2004. Environmental changes in Sepetiba Bay, SE Brazil. Regional Environmental Change 4, 17-27. http://dx.doi.org/10.1007/s10113-003-0060-9

Montezuma, P.N. de, 2007. Impactos nos processos de assoreamento na baía de Sepetiba-RJ, de sedimentos oriundos da bacia contribuinte e de dragagens portuárias. MsD thesis, Universidade Federal do Rio de Janeiro, Rio de Janeiro, 96 p.

Moraes, A.C.R., 1999. Contribuições para a gestão da zona costeira do Brasil. São Paulo, Hucitec; São Paulo: Edusp.

Moreno, C., Kato, K., 2015. Baía de Sepetiba: fronteira do desenvolvimentismo e os limites para a construção de alternativas. 1th Edition. PACS - Instituto Políticas 
Alternativas para o Cone Sul, Rio de Janeiro, 124 p. www.pacs.org.br

Moura, C.A.V., Gaudette, H.E., Carvalho, M.C., Morales, G.P., 2004. The use of lead isotope composition as a tool to investigate the anthropogenic impacts on the environment in the metropolitan region of Belem (PA). Terrae 1, 9-18.

Neto, A.C.L., Legey, L.F.L., González-Araya, M.C., Jablonski, S., 2006. A system dynamics model for the environmental management of the Sepetiba bay watershed, Brazil. Environmental Management 38, 879888. https://doi.org/10.1007/s00267-005-0211-5

Patchineelam, S.M., Sanders, C.J., Smoak, J.M., Zem, R.C., Oliveira, G., Patchineelam, S.R., 2011. A historical evaluation of anthropogenic impact in coastal ecosystems by geochemical signatures. Journal of the Brazilian Chemical Society 22 (1), 120-125. http://dx.doi.org/10.1590/S010350532011000100016

Patterson C., Settle D., Glover, B., 1976. Analysis of lead in polluted coastal seawater. Marine Chemistry 4, 305-319. https://doi.org/10.1016/0304-4203(76)90017-7

Pellegatti, F., Figueiredo, A.M.G., Wasserman, J.C., 2007. Neutron activation analysis applied to the determination of heavy metals and other trace elements in sediments from Sepetiba Bay (RJ), Brazil. Geostandards and Geoanalytical Research 25 (2-3), 307-315. 908X.2001.tb00607.x

Pellegatti, F., 2000. Determinação de metais pesados e outros elementos em sedimentos da Baía de Sepetiba (RJ), por ativação neutrônica. MsD Thesis, Universidade de São Paulo, São Paulo, Brazil, 119 p.

Potratz, G.L., Geraldes, M.G.G., Bizzi, S., Nogueira, L., Alves Martins, M.V., 2019. Using lead isotopes and potentially toxic elements to trace pollutant sources in the northern region of Guanabara Bay, southeastern Brazil. Marine Pollution Bulletin 144, 216-223. https://doi.org/10.1016/j.marpolbul.2019.04.057

Ribeiro, A.P., Figueiredo, A.M.G., Santos, J.O., Ferreira, P.A., Graudenz, G.S., Ruiz, M. S., Mahiques, M., Figueira, R.C., Wasserman, J.C., 2015. Effects of contamination with toxic metals on the environmental quality of Sepetiba Bay (SE Brazil). Management of Environmental Quality 26, 538-551. http://dx.doi.org/10.1108/meq-06-2013-0074

Rio de Janeiro (Estado), 2001. Secretaria de Meio Ambiente e Desenvolvimento Sustentável. Bacias e Recursos Hídricos da
RESEARCH PAPER

Macrorregião 2 - Bacia da Baía de Sepetiba. Projeto PlanáguaSEMADS/GTZ. Rio de Janeiro: SEMADS, Relatório Técnico, $79 \mathrm{p}$.

Rocha, D.S., 2011. Estudos de metais pesados e isótopos de $\mathrm{Pb}$ nos sedimentos da baía de Sepetiba baseado em Geoquímica e nas possíveis áreas fontes. MsD Thesis, Universidade do Estado do Rio de Janeiro, Rio de Janeiro, 112 p.

Rocha, D.S., Cunha, B.C.A., Geraldes, M.C., Pereira, S.D, and Almeida, A.C. 2010. Metais pesados em sedimentos da baía de Sepetiba, RJ: implicações sobre fontes e dinâmica da distribuição pelas correntes de maré. Geochimica Brasiliensis 24, 63-70. https://doi.org/10.21715/gb.v24i1.321

Rusiecka, D., Gledhill, M., Milne, A., Achterberg, E.P., Annett, A.L., Atkinson, S., et al., 2018. Anthropogenic signatures of lead in the Northeast Atlantic. Geophysical Research Letters, 45, 2734-2743. https://doi.org/10.1002/2017GL076825

Santos, S.N., Lafon, J.M., Corrêa, J.A.M., Babinski, M., Dias, F.F., Taddei, M.H.T., 2012. Distribuição e assinatura isotópica de $\mathrm{Pb}$ em sedimentos de fundo da foz do rio Guamá e da Baía do Guajará (Belém - Pará). Química Nova 35 (2), 249-256. http://dx.doi.org/10.1590/S0100-

Simonetti, A., Clément Gariépy, C., Carignan, J., Poissant, L., 2000. Isotopic evidence of trace metal sources and transport in eastern Canada as recorded from wet deposition. Journal of Geophysical Research Atmospheres 105 (D10), 12263-12278. http://dx.doi.org/10.1029/2000JD900073

Sun, G.X., Wang, X.J., Hu, Q.H., 2011. Using stable lead isotopes to trace heavy metal contamination sources in sediments of Xiangjiang and Lishui Rivers in China. Environmental Pollution 159, 3406-3410. https://doi.org/10.1016/j.envpol.2011.08.037

Tarzia, M., de Vivo, B., Somma, R., Ayuso, R. A., McGill, R. A. R., Parrish, R. R.,2002. Anthropogenic vs. natural pollution: An environmental study of an industrial site under remediation (Naples, Italy). Geochemistry Exploration Environment Analysis 2(1):45-56. http://dx.doi.org/10.1144/1467-787302006

Wasserman, J.C., Figueiredo, A.M.G., Pellegatti, F., Silva-Filho, E.V., 2001. Elemental composition of sediment cores from a mangrove environment using neutron activation analysis. Journal of Geochemical Exploration 72, 129-146. http://dx.doi.org/10.1016/S0375-6742(01)00158 